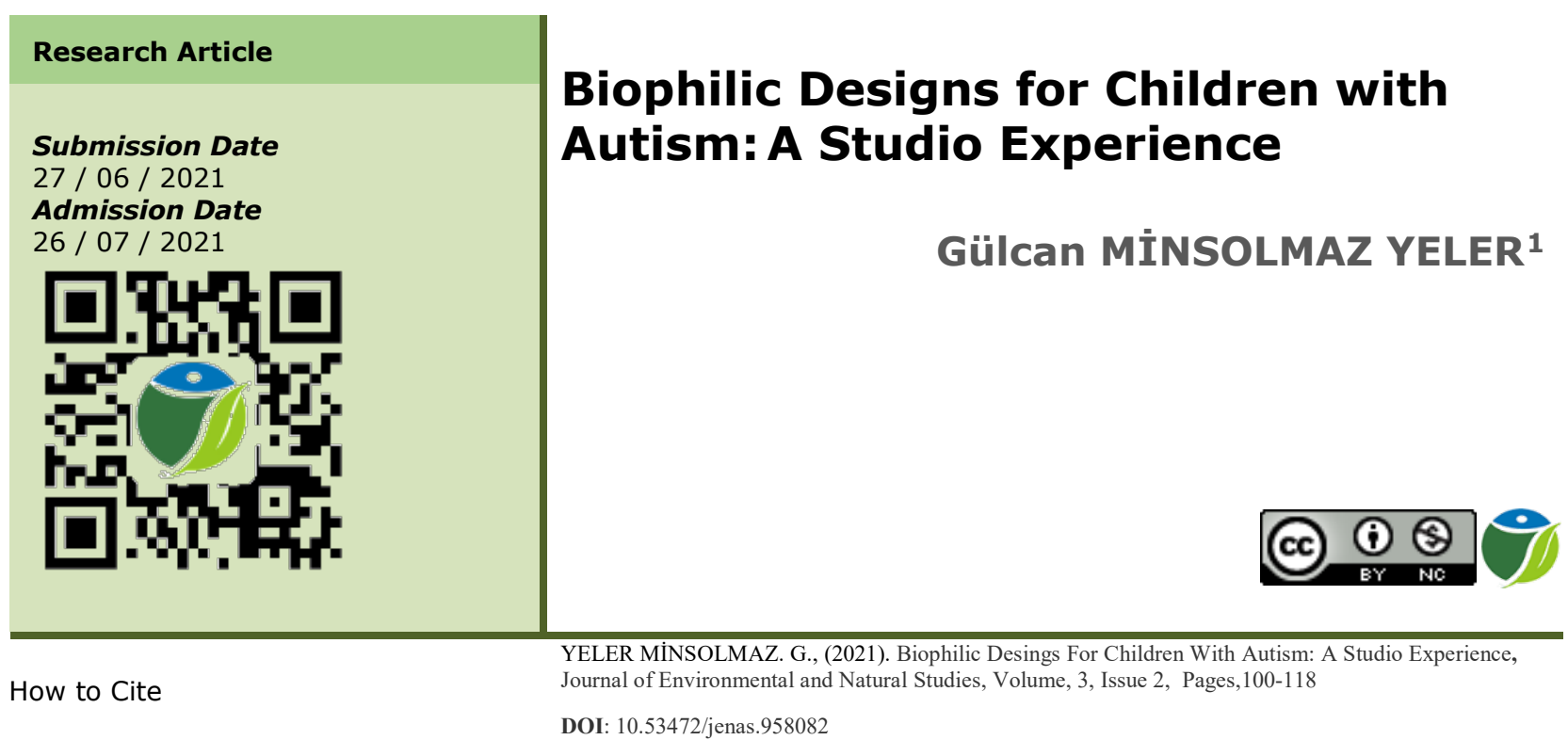

\title{
Otizmli Çocuklar İçin Biyofilik Tasarımlar: Bir Atölye Deneyimi
}

\begin{abstract}
:
Biophilic design has become a preferred approach in achieving a healthy built environment integrated with nature in the architectural environment. The transfer of nature to design by being aware of its multi-faceted benefits is an important process that should be considered by architects. Considering that the user group is children/individuals with autism (Autism Spectrum Disorder), the issue of increasing the quality of life and transferring the healing feature of nature to design becomes even more important to comprehend the human-nature-space-design relationship. The necessity of producing space with this understanding necessitates new inquiries in architectural education. Due to the importance of the subject, the main theme of the Architectural Project IV course of the Department of Architecture, Faculty of Architecture, Kırklareli University has been determined as "Biophilic Designs for Children with Autism". The study tackles the said workshop process. Three different topics have been proposed in order to understand the needs of people with autism from early childhood to adulthood in the places where they live, and to produce spatial solutions to the expectations of the family and society. It is foreseen that biophilic design will be a powerful approach while constructing the relationship between nature and space within the scope of the subjects. Within the scope of the study, it has been tried to understand why, how and to what extent students use their biophilic design experience and qualifications in their designs. Afterwards, evaluations were made on the designs produced in the workshop and student comments. As a result, it has been determined that the designs developed depending on the selected design topics contribute to the understanding of the needs of the user groups with special conditions, raising their awareness, understanding the human-nature-space-design relationship, associating the biophilic design with their own designs, and developing designs that will cover everyone.
\end{abstract}

KEYWORDS: Autism (Autism Spectrum Disorder), nature, space, biophilic design, workshop experience.

${ }^{1}$ Kırklareli Üniversitesi, Mimarlık Fakültesi, Mimarlık Bölümü, Kayalı Yerleşkesi, 1. Derslik Binası, Kayalı, Kırklareli gulcan.yeler@klu.edu.tr ORCID NO: 0000-0002-8259-8071 


\section{ÖZ:}

Biyofilik tasarım, mimarlık ortamında doğa ile bütünleştirilmiş sağlıklı bir yapılı çevre elde edilmesinde tercih edilen bir yaklaşım haline gelmiştir. Doğanın, çok yönlü faydalarının farkında olarak tasarıma aktarılması, mimarlar tarafından dikkate alınması gereken önemli bir süreçtir. Kullanıcı grubunun otizmli (Otizm Spektrum Bozukluğu) çocuklar/bireyler olduğu düşünüldüğünde, yaşam kalitesinin artırılması ve doğanın iyileştirici özelliğinin tasarıma aktarılması konusu, insan-doğa-mekân-tasarım ilişkisinin kavranmasını daha da önemli hale getirmektedir. Bu kavrayışla mekân üretilmesi gerekliliği, mimarlık eğitiminde yeni sorgulamaları zorunlu kılmaktadır. Konunun önemi nedeniyle, Kırklareli Üniversitesi Mimarlık Fakültesi Mimarlık Bölümü Mimari Proje IV dersinin ana teması "Otizmli Çocuklar İ çin Biyofilik Tasarımlar" olarak belirlenmiştir. Çalışma, sözü edilen atölye sürecini ele almaktadır. Atölyede, otizmlilerin erken çocukluktan yetişkinliğe olan süreçte, yaşamlarının geçtiği mekânlarda ihtiyaçlarını anlayabilmek, aile ve toplumun da beklentilerine mekânsal olarak çözümler üretebilmek amacıyla üç farklı tasarım konusu önerilmiştir. Konular kapsamında doğa ve mekân arasındaki ilişki kurgulanırken biyofilik tasarımın güçlü bir yaklaşım olacağı öngörülmüştür. Çalışma kapsamında da, öğrencilerin tasarımlarında biyofilik tasarım deneyim ve niteliklerini neden, nasıl ve ne ölçüde kullandıkları anlaşılmaya çalışılmıştır. Sonrasında, atölyede üretilen tasarımlar ve öğrenci yorumları üzerinden değerlendirmeler yapılmıştır. Sonuç olarak, seçilen tasarım konularına bağlı olarak geliştirilen tasarımların, mimarlık öğrencilerinin özel durumları olan kullanıcı gruplarının ihtiyaçlarını anlamalarında, farkındalıklarını artırmalarında, insan-doğa-mekân-tasarım ilişkisinin kavranmasında, biyofilik tasarımı kendi tasarımları ile ilişkilendirmelerinde, herkesi kapsayacak tasarımlar geliştirmelerinde katkı sağladığı tespit edilmiştir.

ANAHTAR KELIMER: Otizm (Otizm Spektrum Bozukluğu), doğa, mekân, biyofilik tasarım, atölye deneyimi.

\section{GíRiş:}

Otizm, yani yeni adıyla Otizm Spektrum Bozukluğu (OSB), Arslan (2020)'nın da belirttiği gibi, çocukluk döneminde kendini gösteren ve bireyin tüm yaşamı boyunca devam eden, sosyal etkileşim ve iletişim alanında yaşanan zorlukları ve gelişimsel gerilikleri ifade etmektedir. Otizm, çocukları çok farklı şekillerde etkileyebilmekte ve otizmli çocukların özellikleri birbirinden farklı olabilmektedir. Bir çocukta yoğun olarak görülen davranış ya da belirtiler diğer çocukta hiç görülmediğinden, otizmin çocuklar üzerindeki etkisi, çocukların özelliklerine göre hafiften ağıra doğru bir yelpaze içinde değerlendirilmektedir (Arslan, 2020). Amerikan Psikiyatri Birliği'nin yayımladığı kılavuza göre otizm, iki alandaki yetersizlikle kendini göstermektedir (Tohum Otizm Vakfi, 2020). Birincisi, toplumsal iletişim ve etkileşimde güçlükler (iliş̧ki kurma ve sürdürmede zorlanma, göz kontağı kuramama, duyguları ifade edememe, etkileşim başlatma ve sürdürmede zorlanma) ve ikincisi de, sınırl1-yineleyici davranış örüntüler yani tekrarlayıcı davranışlar (basmakalıp ve tekrarlayıcı motor hareketler, aynılıkta 1srar, rutine sıkı bağlılık, sınırlı ve yoğun ilgi alanı, duyusal az veya çok uyarılma) dir.

Önceki yıllarda otizmin görülme oranının 500'de 1 olduğu kabul edilirken, son verilere göre, yaklaşık her 54 çocuktan 1 'ini etkilediği düşünülmektedir. Ancak, erken tanı ve doğru bir eğitim yöntemi ile yoğun olarak eğitim alan çocukların yaklaşık yüzde ellisinde otizmin belirtileri kontrol altına alınabilmekte, gelişim sağlanabilmekte, büyük ilerleme kaydedilmekte ve hatta bazı otizmli çocukların ergenlik yaşına geldiklerinde diğer arkadaşlarından farksız olabilmektedir (Tohum Otizm Vakfi, 2020). Burak ve Ahmetoğlu (2020), Otizm Spektrum Bozukluğu (OSB) olan bireylerin, sosyal yaşama kazandırılmaları veya üretken bireyler haline gelmelerinin yeterli düzeyde eğitim imkânlarının sunulmasına bağlı olduğunu belirtmektedir. Çocuklar ne kadar erken yaşta yoğun eğitim alırlarsa; yetişkin olduklarında o kadar bağımsız, kendine yeten, üretken, ekonomiye katkı sağlayan bireyler olarak toplum içinde yer alabileceklerdir.

Ancak, günümüzde otizmli çocukların toplum içinde var olmaları da giderek zorlaşmaktadır. Çocukların sosyal etkileşim yetersizlikleri, içe kapanıklık ve uygun olmayan davranışları bakımından sosyal çevreleri tarafından dışlandıkları, ailelerin zamanlarının ve enerjilerinin büyük bir kısmını çocukları için harcadıkları ve bu süreçte zorluklarla karşılaştıkları bilinmektedir (Nealy vd, 2012; Özkubati vd. 2014,). Bu durumun oluşmasında, bina ve kentlerin, genel anlamda yapılı çevrenin otizmliler için uygun tasarlanmamış olması da önemli bir etkendir. Yapılı çevre, doğadan oldukça yoksundur. Bireylerin rahatlayacakları alanlar çok kısıtlıdır. Bu yönleriyle, sağlıklı bir yapılı çevre elde edilmesinde doğanın tasarımla bütünleştirilmesi önemli bir yaklaşım olmaktadır. Bu kapsamda, otizmlileri anlamak ve onlara yaşanabilir çevreler sunmak, doğanın iyileştirici özelliğinin tasarıma aktarmak sürecinde insan-doğamekân-tasarım ilişkisinin kavranması anlamlı olacaktır. 


\section{Kuramsal Bakıș}

\subsection{Otizm, Mekân, Tasarım, Doğa İlişkisi}

Yapılı çevrenin otizmli çocukların/bireylerin yaşam kalitesinde etkili bir faktör olduğu dikkate alındığında, tasarımın öncelikle eğitim ortamlarından başlayarak diğer mekânlara ve kente kadar gelişim gösteren bir yelpazede özenle ele alınması gerekliliği ortaya çıkmaktadır. Bu noktada, (Tola vd, 2021), her bireyin farklı semptomları ve hassasiyetleri olduğu göz önünde bulundurulduğunda, yapılı çevrenin otizmli insanları nasıl etkilediğini ve kendilerine yetebilmelerini teşvik etmek, genel yaşam kalitelerini artırmak için nasıl tasarlanıp düzenlenebileceğinin araştırılmasının önemli olduğunu vurgulamaktadır. Çünkü kapalı ve açık mekânlarda mevcut olan kısıtlamalar nedeniyle otizmli bireyler sorunlar yaşamaktadırlar. Mimar John Jenkins'in, otistik çocuklar için eğitim alanlarının tasarımına ilişkin olarak belirttiği gibi, normal gelişim gösteren çocuklar muhtemelen kötü tasarlanmış mekânlarla, otistik bir çocuğa nazaran daha kolay başa çıabilmektedirler. Bu durum, her yaştan insana ve diğer bina türlerine de genelleştirilebilir. Bu nedenle yapılı çevrede otizmliler için "iyi bir ortam" yaratma sorumluluğu keskin bir şekilde ortaya çıkmaktadır (Vázquez ve Torres, 2013). Ancak, otizmliler için tasarım yapmak, otizm ve özellikleri hakkında kapsamlı bir bilgi gerektirmektedir. Otizmlilerin başkalarıyla nasıl iletişim kurduğunu, onların dünyalarını nasıl algıladıklarını ve olaylarla nasıl etkileşime girdiklerini (Elafifi ve Abdelaziz Farid, 2020), çevreyi ve içindeki insanları, nesneleri nasıl deneyimlediklerini, ne tür duyusal farklılıklar sergilediklerini, her bireyin olaylar karşısında aynı şekilde veya aynı ölçüde etkilenmediklerini (Scott, 2009) bilmek tasarım sürecinde önem kazanmaktadır.

Mimarlık, özne nesne ilişkisinden hareketle, insanın ihtiyaçlarını giderme aracıdır. Bu nedenle mimarlık olanı değil de olması gerekene kafa yormaktır (Ergül, 2015). Bu kapsamda, otizmli bireylerin günümüzde yaşadıkları pek çok soruna kafa yormak, çözüm üretmek ve otizm dostu bir yapılı çevre yaratmak mimarlığın sorumluluk alanına girmektedir. Mimarların, toplumda otistik insanların varlığı kabul edildikten ve otistik eksiklikler belirlenip anlaşıldıktan sonra, fiziksel veya görme engelli kişilerle ilgili politikalara benzer şekilde, otistik entegrasyon için de çözümler sunmaları gerekmektedir (Pomana, 2015). Issa (2017), mimarların otizmlilerin bulundukları tüm mekânlarda uygun ortamı sağlayarak bu nörogelişimsel bozukluğa karşı savaşta yardımcı olabileceklerini, bir dizi önlem ve stratejiler ile çocukların gelişimine, eğitimine, topluma katılmasına ve sosyalleşmesine önemli katkılar sağlayabileceğini belirtmektedir. Ayrıca, belirli tasarım öğelerinin çocukların davranışları üzerinde büyük etkisi olduğu için, mimarların mimariyi kapsayıcı barınma ortamları sağlayacak şekilde benimseyerek, bu bireylere daha iyi, yaşam kalitesini artıran ve firsat eşitliği yaratan çözümler üretebileceklerini vurgulamaktadır. Konunun öneminin anlaşılmasıyla, bu yönde tasarım fikirleri ve çözümleri üreten çalışmalar (Beaver, 2006; Mostafa, 2008; Mostafa, 2014; Humphreys, 2008; Scott, 2009) da giderek artmaktadır.

Otizmle ilgili sorunları ele almak, bu bireylerin potansiyellerine ulaşmalarına yardımcı olmak amacıyla son zamanlarda “doğanın iyileştirici gücü” üzerinde durulmaktadır. Doğa ile bağlantının oldukça azalmış olduğu günümüzde, Barakat ve El-Sayad (2019)'unda belirttiği gibi, OSB'li çocukların doğayla iletişim ve bağlantı kurmaları bilişsel, zihinsel, fiziksel, sosyal ve duygusal açıdan pek çok fayda sağlamaktadır (Tablo 1).

Tablo 1. Otizmli çocuklar için doğayla bağ kurmanın faydaları (Barakat ve El-Sayad (2019)'dan geliştirilmiştir.)

\begin{tabular}{l}
$\qquad$ DOĞAYLA BAĞ KURMANIN FAYDALARI \\
\hline Bilişsel faydalar \\
\hline Doğada geçirilen zaman, gözlem yapmaya ve daha yaratıcı olmaya yardımcı olur. \\
Doğal ortamlarda oyun, işbirlikçi becerileri ve dil gelişimini güçlendirir. \\
Açık hava becerileri eğitimi çocukların sağlığına, yaşam tarzına ve öğrenimine yardımcı olur. \\
\hline Zihinsel faydalar \\
\hline Doğa stresi azaltmaya yardımcı olur. \\
Doğa olumlu duyguları güçlendirir. \\
Güneş ışı̆̆ına maruz kalmak, D vitamini üretimini artırır, şişmanlığı azaltır. \\
Açık alanda yürüyüş, dikkat eksikliği/hiperaktivite bozukluğu olan çocukların odaklanmaları artırır. \\
\hline Fiziksel sağlık bakımından faydalar \\
\hline Doğa deneyimleri dengeyi, çevikliği ve koordinasyonu geliştirir. \\
Dış mekânlarda daha fazla zaman geçiren çocuklar daha aktif olur. \\
Daha fazla riske sahip olan açı oyun alanları, geleneksel oyun alanlarından daha az kazaya sebep olur. \\
\hline Diğer faydalar \\
\hline Sosyal gelişim \\
Duygusal gelişme
\end{tabular}


Bu kapsamda, insanların yaşamak, öğrenmek ve çalışmak için doğal ortamlar yaratılmasını hedefleyen "biyofilik tasarım”, doğa ile bağlantı kurmanın yenilikçi bir yöntemi olmaktadır.

Ayrıca, herkesin eşit olduğu bir toplumda, yukarıda sözü edilen sorunlara da çözüm üretebilmek adına, sadece belirli bir kesim için yapılan tasarımlar yerine herkesi kapsayan "herkes için tasarım" yani "evrensel tasarım" anlayışının da yaygınlaşması önem kazanmaktadır.

\subsection{Biyofilik Tasarım}

Yaşam sevgisi ve yaşam süreçleri anlamına gelen biyofili, ilk kez psikanalist Erich Fromm (1964) tarafından, daha sonra da biyolog Edward Wilson (1984) tarafından popüler hale getirilen bir terimdir. Wilson, "Biophilia" adlı kitabında biyofiliyi "yaşama ve gerçeğe yakın süreçlere odaklanmaya yönelik doğuştan gelen eğilim" olarak tanımlamıştır.

İnsanın doğa sevgisini tekrar hissettiği, doğa ile içsel bağını bütünleştirdiği biyofilik tasarım, günümüz trendi olan modern mimarinin tasarım parametreleri ile harmanlanarak yeni bir yaklaşım olarak (Yurtgün, 2020) değerlendirilmektedir. Biyofilik tasarımın temel amacı, insanın performans ve refahı için modern yaşamda da kritik olmayı sürdüren doğal sistem ve süreçlerle olumlu deneyim ihtiyacının yapılı çevrede sağlanması ve sürdürülmesidir (Kellert vd., 2008).

Biyofilik tasarım uygulaması, deneyimler ve nitelikler olarak adlandırılan çeşitli tasarım stratejilerinin uygulanmasını içermektedir (Kellert vd., 2008; Kellert ve Calabrese, 2015; Ryan vd., 2014). Çalışma kapsamında Kellert ve Calabrese (2015)'nin biyofilik tasarım için önerdiği "doğrudan doğa deneyimi", "dolaylı doğa deneyimi” ve "mekân ve yer deneyimi”" olmak üzere üç kategori esas alınmıştır (Table 2). Doğanın doğrudan deneyimi; doğal ışık, hava, bitkiler, hayvanlar, su, manzaralar vd. dahil olmak üzere yapılı çevredeki çevresel özelliklerle doğrudan teması ifade etmektedir. Doğanın dolaylı deneyimi, doğanın temsili ya da imgesi ile temasa, doğanın orijinal durumundan dönüşümüne ya da doğal dünyaya özgü belirli kalıplara ve süreçlere maruz kalmaya atıfta bulunmaktadır. Son olarak, mekân ve yer deneyimi de, gelişmiş insan sağlığı ve refahına sahip olan doğal çevrenin karakteristiği olan mekânsal özellikleri dikkate almaktadır. Bu üç deneyim kategorisi içinde, biyofilik tasarımın 24 özelliği tanımlanmıştır.

Tablo 2. Biyofilik tasarımın deneyimleri ve özellikleri (Kellert ve Calabrese (2015)'den düzenlenmiştir.)

\section{BIYOFILIK TASARIMIN DENEYIMLERİ VE ÖZELLIKLERİ}

DOĞANIN DOĞRUDAN DENEYIMI
Iş1k, hava, su, bitkiler, hayvanlar, hava durumu, doğal peyzaj ekosistemleri ve ateş.

Doğa görüntüleri, doğal malzemeler, doğal renkler, doğal 1ş1k ve havayı simüle eden, doğal şekiller ve formlar, doğayı çağrıştırma, bilgi zenginliği, zamanın değişimi, doğal geometriler ve biyomimikri.

\section{MEKÂN VE YER DENEYIMI}

Gözetleme, sığınma, organize karmaşıklık, parçaların bütüne entegrasyonu, geçiş alanları, hareketlilik ve yön bulma, yere kültürel ve ekolojik bağlılık.

Belirlenen parametreler, iç ve diş mekânlar için geniş uygulama imkânına sahip, uygulanabilir ve esnek modeller olarak belirtilmiştir. Bu tasarım modelleri, stres faktörlerini hafifletmeye ve mekânların niteliklerini arttırmaya odaklanmıştır (Browning vd., 2014).

\subsection{Evrensel Tasarım}

Evrensel tasarım; fizyolojik özelliklerine, yaşına, cinsiyetine, sosyal, ekonomik ve eğitim düzeyine bakılmaksızın, toplumdaki farklı özelliklere sahip tüm insan grupları için ortak tasarımlar yapmayı amaçlamaktadır. Önemli olan ürün, hizmet ve fiziksel çevrenin her zaman her koşulda kullanabilir olmasıdır (Zeyrek Çepehan ve Güller, 2020). Evrensel tasarım, engelli bireylere veya toplumun herhangi bir bölümüne yönelik ayrımcı çözümlere fikir olarak karşı çıkmakta, toplum içerisinde bulunan her bireyin kentsel kullanım alanlarını eşit koşullarda kullanabilmesine vurgu yapmaktadır (Tandoğan, 2017). Evrensel tasarım, engelliler için özel tasarımlar yapıp onları toplumda hedef kitle almak yerine; tasarım yaparken dikkate aldığı geniş hedef kitlesinin içerisine katarak onları toplumla bütünleştirmeyi amaçlamaktadır (Duman, 2017). Evrensel tasarım kapsamında mekânların, tüm kullanıcı grupları tarafından rahat, güvenli ve bağımsız şekilde kullanılabilmesi ve kolay erişilebilir olması beklenmektedir. Bu kapsamda, mimari tasarım sürecinde de, 
tasarımcı merkezli anlayışın yerini kullanıcının önemsendiği bir anlayışın esas alınması gerekliliği ortaya çıkmaktadır. Yaş, bedensel özellik, kişisel gelişim ve beceri farkı gözetmeksizin, tüm kullanıcılara ait farklılıkların önemsenmesi, kullanıcı deneyimlerinin anlaşılması, kullanıcının fizyolojik ve psikolojik gereksinimlerine ek olarak ruhsal ve duygusal açıdan da özel gereksinimlerinin karşılanması tasarım sürecinin temel konularını oluşturmaktadır. Tasarımcının kullanıcının yerine kendini koyması ve eşit kullanım, esnek kullanım, basit ve sezgisel kullanım, algılanabilir bilgi, hata toleransı, düşük fiziksel güç, yaklaşım ve kullanım için yeterli alan olarak belirlenmiş yedi evrensel tasarım ilkesini yol gösterici olarak dikkate alması, iyi tasarım yapmasında yardımcı olacaktır (Duman, 2017; Zeyrek Çepehan ve Güller, 2020).

\section{2. Çalışmanın Amacı, Kapsamı ve Yöntemi}

\section{1. Çalışmanın Amacı}

Çalışmanın amacı, öncelikle, otizmli bireylerin zihinsel ve duygusal yönden gelişimlerini hızlandırmak, sosyal beceriler kazanmasını sağlamak, olumsuz davranışlarını azaltmak yönünde doğanın fiziksel, zihinsel ve psikolojik yönden iyileştirici özelliklerini de göz önünde bulundurarak doğa ile etkileşimli iç ve dış mekânlar yaratılmasını sağlamaktır. Bu kavrayışın mimarlık eğitimi sürecinde kazanılacağı düşüncesinden yola çıkarak, sözü edilen yararlı yönleriyle doğa ve mekân arasındaki ilişkinin kurgulanmasında, biyofilik tasarımın güçlü bir yaklaşım olacağı öngörülmüştür. Bu bağlamda, Kırklareli Üniversitesi Mimarlık Fakültesi Mimarlık Bölümü 2019-2020 Güz Yarıyılında 3. Sınıfların Mimari Proje IV dersinin ana teması "Otizmli Çocuklar İçin Biyofilik Tasarımlar" olarak belirlenmiştir. Atölye sürecinde, mimarlık öğrencilerinin, özel durumları olan kullanıcı gruplarının ihtiyaçlarını anlamaları, otizmliler konusunda farkındalıklarının çok yönlü gelişmesini sağlamaları, biyofilik tasarım ilkelerini tasarımları ile bütünleştirebilmeleri, ayrıca, evrensel tasarım ilkeleri çerçevesinde de herkesi kapsayacak şekilde tasarımlar geliştirmeleri hedeflenmiştir.

\section{2. Çalışmanın Kapsamı}

Bu çalışma ise, sözü edilen "Otizmli Çocuklar İçin Biyofilik Tasarımlar" temalı atölye sürecini kapsamaktadır. Mimarlık öğrencilerinin yukarıda ifade edilen hedeflere ulaşabilmeleri, ayrıca, otizmli çocukların çok yönlü gelişimini ve sosyalleşmelerini sağlayabilmek adına farklı mekânlarda deneyimlerini anlayabilmeleri ve bu mekanlara dair tasarım önerileri geliştirebilmeleri adına tasarım konuları geniş tutulmuştur. Çalışmada, daha çok biyofilik tasarıma odaklanılmış, öğrencilerin tasarımlarında biyofilik tasarım deneyim ve niteliklerini neden, nasıl ve ne ölçüde kullandıkları anlaşılmaya çalışılmıştır. Çalışmayı sınırlandırmak anlamında, evrensel tasarım konusuna genel olarak değinilmiş, daha çok proje sürecinde öğrencilere etkileri ve kazanımları ortaya konmuştur.

\section{3. Çalışmanın Yöntemi}

Çalışma yöntemi olarak, öncelikle, literatür araştırmasıyla kuramsal bir bakış kurulmuş, genel olarak otizm-mekantasarım-doğa ilişkisi kavranmaya çalışılmıştır. Ayrıca, öğrenci tasarımlarında uygulanması beklenen ana tasarım yaklaşımı olarak biyofilik tasarım kavramı, deneyimleri ve nitelikleri üzerinde durulmuştur. Çalışma kapsamında Kellert ve Calabrese (2015)'nin biyofilik tasarım için önerdiği "doğrudan doğa deneyimi”, "dolaylı doğa deneyimi” ve "mekân ve yer deneyimi" olmak üzere üç kategori esas alınmıştır. Bunun yanı sıra, evrensel tasarım konusuna değinilmiş ve önemi vurgulanmıştır. Sonrasında çalışmanın ana konusu olan“ atölye süreci” ele alınmıştır. Atölye sürecinde, tasarım konuları ve bu konuların seçilmesinde hedefler ortaya konmuştur. Atölye programı ise araştırma, tasarım, sergileme ve değerlendirme aşamaları olmak üzere dört başlıkta incelenmiştir. Öğrencilerin atölye sürecinde tüm deneyimlerinden elde ettikleri kazanımları ve yaşadıkları zorlukları anlayabilmek, biyofilik tasarımın deneyimleri ve nitelikleri ile tasarımlarında nasıl bir ilişki kurduklarını kavrayabilmek adına öğrenci tasarımları ve yorumları üzerinden değerlendirmelerde bulunulmuştur. Çalışmada yer verilen değerlendirmeler kapsamında, atölyede üretilen tasarımlar hakkında genel bir fikir edinilmesi bakımından 16 adet öğrencinin tasarım posterlerine yer verilmiştir. Biyofilik tasarımın uygulanması konusunda daha detaylı anlatımlar ise tasarımları Arkitera Mimarlık Merkezinin web sitesinde yer almış iki öğrencinin çalışmaları üzerinden yapılmışıır. 


\section{3. “Otizmliler İçin Biyofilik Tasarımlar” Temalı Atölye Süreci}

\subsection{Konularm Belirlenmesi}

Proje konuları, proje dönemi öncesinde, otizmliler ile ilgilenen öğretmenler ve uzmanlar ile yapılan görüşmeler sonrasında belirlenmiştir. Otizmlilerin erken çocukluktan yetişkinliğe olan süreçte, yaşamlarının geçtiği mekânlarda ihtiyaçlarını ve davranışlarını anlayabilmek, aile ve toplumun da beklentilerine mekânsal olarak çözümler üretebilmek amaciyla üç konu belirlenmiştir:

A. Eğitim Merkezi Tasarımı: Otizm, çocukluk döneminde kendini gösterdiğinden eğitimin çok önemli olduğu ortaya çıkmaktadır. Bu nedenle, erken dönemde başlanan yoğun eğitim programları ile kendilerine yetebilen, bağımsız, üretken, çalışan, toplum içinde yer alan bireyler olmaları hedeflenmiştir.

B. Özel Eğitim ve Rehabilitasyon Merkezi Tasarımı: Otizm, tedavisi olmayan bir rahatsızlık olduğundan çocukların eğitimleri sonrasındaki zamanlarda da özel eğitim ve davranış terapileri ile gelişimlerini hızlandırmak ve bu süreçte aileye yardımcı olmak hedeflenmiştir.

C. Sosyal Yaşam Merkezi Tasarımı: Otizmlilere ve ailelerine boş zamanlarında nefes aldırmak, bireyleri yaşamın içine katmak, sağlıklı çocukların ve insanların da özel durumları olan bireylerin yaşamlarından haberdar olup birlikte kaynaşmalarını sağlayabilmek hedeflenmiştir.

Öğrencilerin sözü edilen proje konularında, belirtilen hedeflere mimari bakış açısıyla çözüm üretmeleri ve uygun mekânlar tasarlamaları sürecinde, doğanın etkili bir öğe olduğu dikkate alınarak "Biyofilik tasarım deneyim ve niteliklerini”, ayrıca "Evrensel tasarım ilkelerini” de kullanmaları beklenmiştir.

\subsection{Atölye Programı}

Proje süreci, belirlenen hedeflere ulaşabilmek için üç aşamada kurgulanmış ve gerçekleştirilmiştir.

\subsubsection{Araştırma Aşaması}

Öğrenciler, tasarıma başlamadan önce konu ile ilgili literatür araştırmaları yaparak otizm ve otizmliler hakkında genel bilgiler edinmiş̧lerdir. Grup çalışmaları ile öğrenciler; otizmlileri anlamak, ihtiyaçlarını belirlemek, bireylerin iç mekân ve dış mekânda davranışlarını sorgulamak amacıyla Kırklareli il merkezinde bulunan 1. 2. ve 3. Kademe Özel Eğitim Okulları ile Özel Eğitim ve Rehabilitasyon Merkezlerini ziyaret etmişlerdir. Araştırma sürecinde öğrencilerin tasarımlarına önemli veriler sunacak tüm bilgiler, stüdyo ortamında sunularak ve tartışılarak gruplar arasında bilgi alışverişi sağlanmıştır. Ayrıca, uzmanlar tarafından verilen seminerler ve izlenilen filmler ile konu pekiştirilmeye çalışılmıştır.

\subsubsection{Tasarım Aşaması}

Öğrencilerin tasarıma geçmeden önce tasarımın ana temasını oluşturan "biyofili" kavramı ve "biyofilik tasarım deneyim ve nitelikleri” ile ilgili bir seminer verilerek mekân ve doğa arasındaki ilişkinin nasıl kurgulanacağı üzerinde tartışmalar yapılmıştır. Tasarımın gerçekleştirileceği arazi, öğrencilerin öngörüleri doğrultusunda mekân-doğa ilişkisini güçlendirecek şekilde seçilebilmesi için öğrencinin tercihine bırakılmıştır. Bu kapsamda tasarım süreci, öğrencilerin seçtikleri konu ve yer özelinde, kullanıcı gruplarını belirleme, kullanıcıların ihtiyaç ve isteklerini analiz etme, ihtiyaç programı oluşturma, konsept geliştirme, yer ve bağlamı çerçevesinde tasarımı geliştirme, biyofilik tasarım deneyim ve niteliklerini tasarım ile bütünleştirme, tasarımı iki ve üç boyutlu anlatımlarla ifade etme gibi aşamalar ile geliştirilmiştir.

\subsubsection{Sergileme Aşaması}

Atölye ortamında yapılan tasarımlardan seçilen projeler, "3 Aralık Engelliler Günü” kapsamında, atölye yürütücüsü tarafindan hazırlanan "Engelleri Kaldır-1. Farkındalık Sergisi" bünyesinde kent merkezinde herkese açık olarak sergilenmiştir. Farklı engellilik durumlarına odaklanan serginin bu bölümünde, çevremizde otizmli bireylerin yaşam kalitesinin artırılmasında doğa ile ilişkilendirilmiş mekân tasarımının önemine dikkat çekmek amaçlanmıştır.

\subsubsection{Değerlendirme Aşaması}


Projelerin tamamlanması sonrasında, öğrencilerin atölye sürecinde tüm deneyimlerinden elde ettikleri kazanımları ve yaşadıkları zorlukları anlayabilmek için bazı başlıklar üzerinden öğrencilerin süreci yorumları beklenmiş ve değerlendirmeler yapılmıştır.

\section{Atölye Sonuçlarının Değerlendirilmesi}

\subsection{Araştırma Sürecinin Değerlendirilmesi}

Çalışmanın otizm-mekân-tasarım-doğa arasındaki ilişkinin ele alındığı bölümde görüldüğü gibi doğa, doğru kurgulanmış bir tasarım ile otizmliler için çok yönlü iyileştirici ve geliştirici faydalar sağlayabilmektedir. Ancak, bu yönleriyle, öğrencilerin Kırklareli İlinde ziyaret edilen okullar ve rehabilitasyon merkezleri değerlendirildiğinde, bu yapıların otizmli çocuklar için çok uygun olmadığı, kapalı-açık ve yarı-açık mekanlarında doğanın elemanlarına ya hiç yer verilmediği ya da sadece açık mekanlarında kısıtlı bir şekilde yer verildiği görülmüştür. Bu binalarda özel gereksinimleri olan çocukların bulunduğu dikkate alındığında, bu çocuklar için özel tasarımlar yapılması gerekirken tam tersine okulların normal çocuklar için tasarlandığı, özel eğitim ve rehabilitasyon merkezlerinin apartman dairelerinden dönüştürüldüğü ya da apartmanların zemin katlarında bu işlevlere yer verildiği saptanmıştır. Bu durum, mimarlık öğrencilerinin yaratıcılıklarının gelişimini olumsuz etkilerken, mekân kaynaklı sorunları yerinde tespit etmeleri bakımından da çok sayıda veri elde etmelerine imkân tanımıstır. Yapılan çalışmalar, öğrencilerin tasarımlarında doğaya maruz kalmayı bir çözüm üretme stratejisi olarak düşünmelerini ve otizmli çocukların ihtiyaçlarını daha iyi karş̧layan mekânlar yaratmaları gerektiği konusunda farkındalıklarını artırmıştır. Öğrenciler kendi yaptıkları araştırmalar, yurtiçi ve yurtdışı örneklerin analiz edilmesi ve yönetmeliklerin incelenmesi ile konuyu pekiştirmişlerdir.

\subsection{Biyofilik Tasarım Deneyim ve Niteliklerinin Tasarımlar ile İliş̧kilendirilmesinin Değerlendirilmesi}

Biyofilik tasarım deneyim ve niteliklerinin öğrenci tasarımları ile ilişkilendirilmesi sürecinde "doğrudan doğa deneyimi, dolaylı doğa deneyimi, mekân ve yer deneyimi” olmak üzere üç başlık üzerinden değerlendirmeler yapılmıştır. Çalışma kapsamında örnek olarak 16 adet projeye ait posterlere yer verilmiş (Tablo 3, 4, 5, 6, 7), değerlendirmelerde atölyede üretilen çalışmalara genel bir bakış yapılmıştır. Ayrıca, biyofilik tasarım ile kurulan ilişkinin daha iyi anlaşılabilmesi için tasarımları Arkitera Mimarlık Merkezinin web sitesinde yer almış Ahmet Furkan Tırpan (Tırpan, 2020) ve Ramazan Çeşmeci (Çeşmeci, 2020) adlı iki öğrencinin çalışmaları üzerinden daha detaylı anlatımlara yer verilmiştir.

Tablo 3. Atölye kapsamında üretilen Eğitim Merkezi Tasarımları

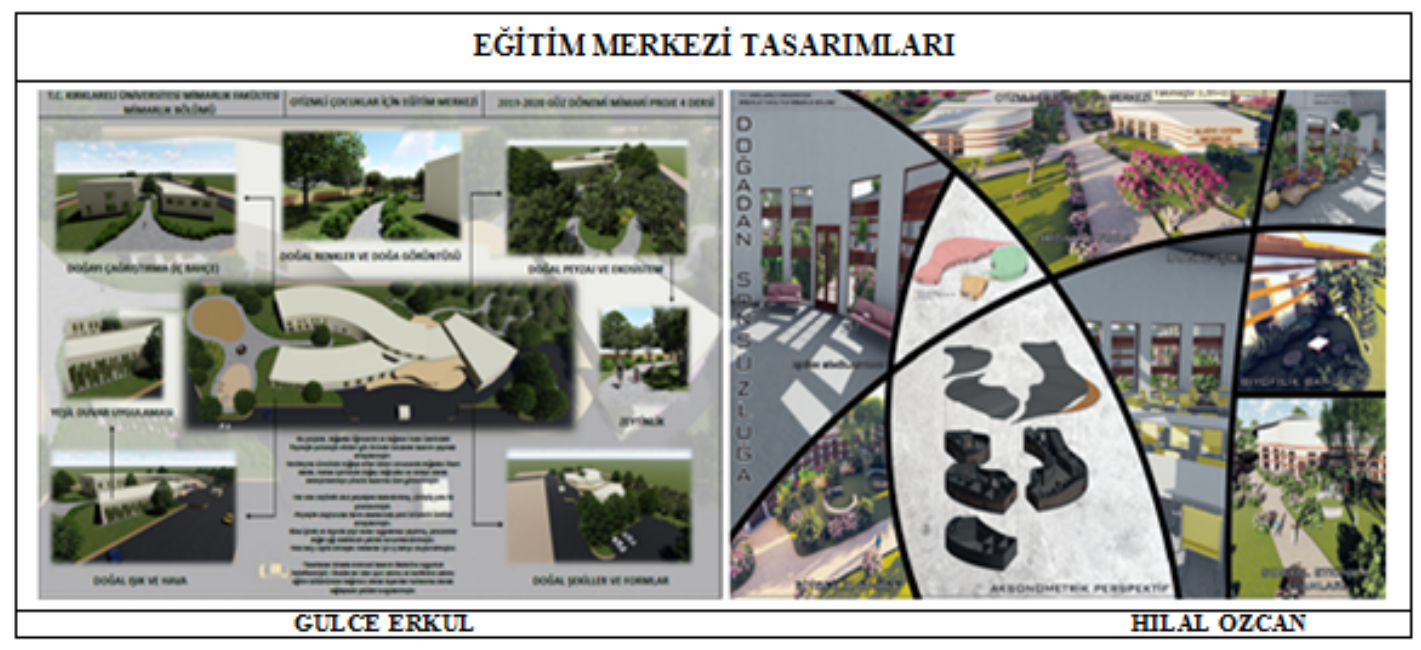

Tablo 4. Atölye kapsamında üretilen Eğitim Merkezi Tasarımları 


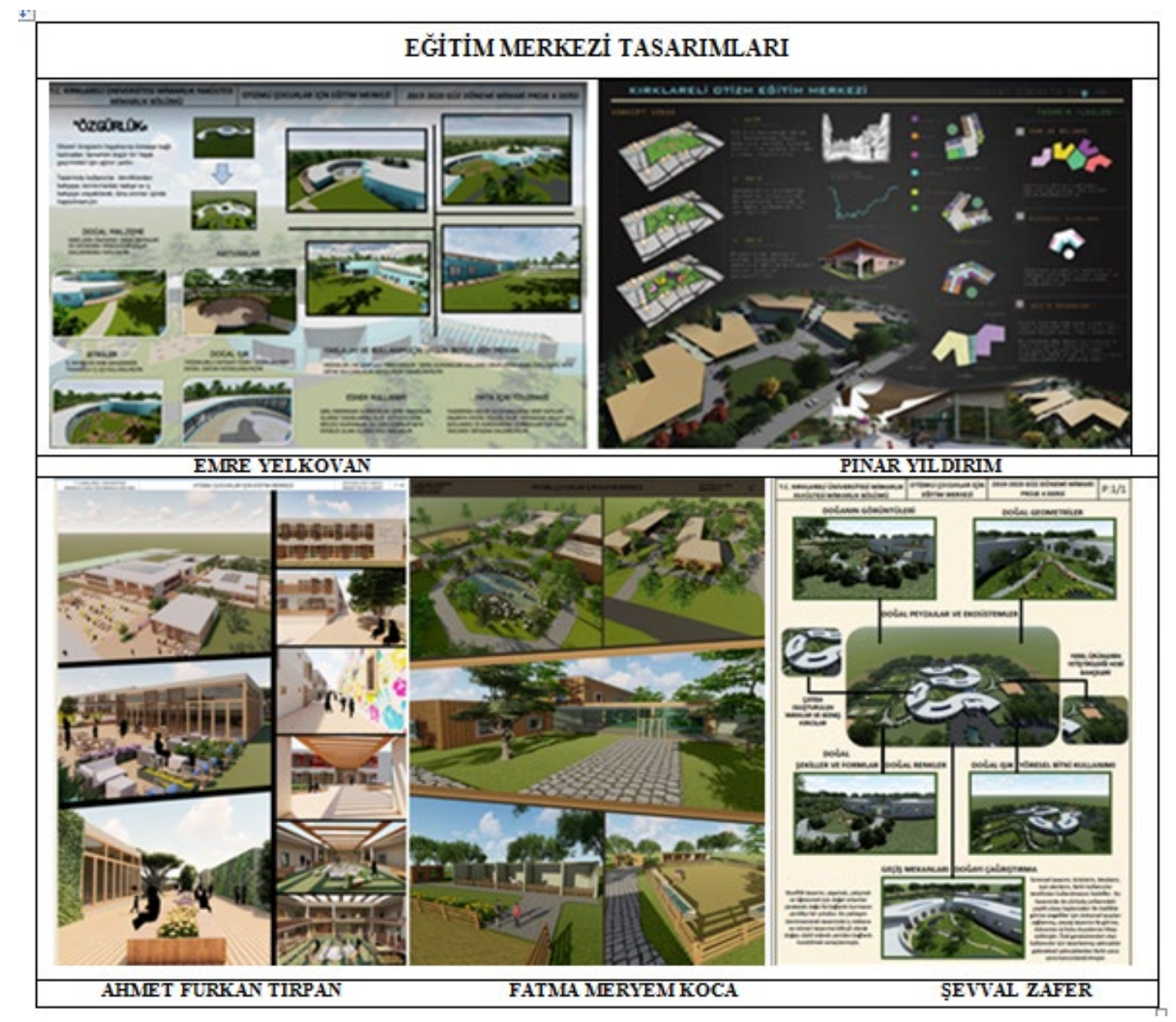

Tablo 5. Atölye kapsamında üretilen Özel Eğitim ve Rehabilitasyon Merkezi Tasarımları

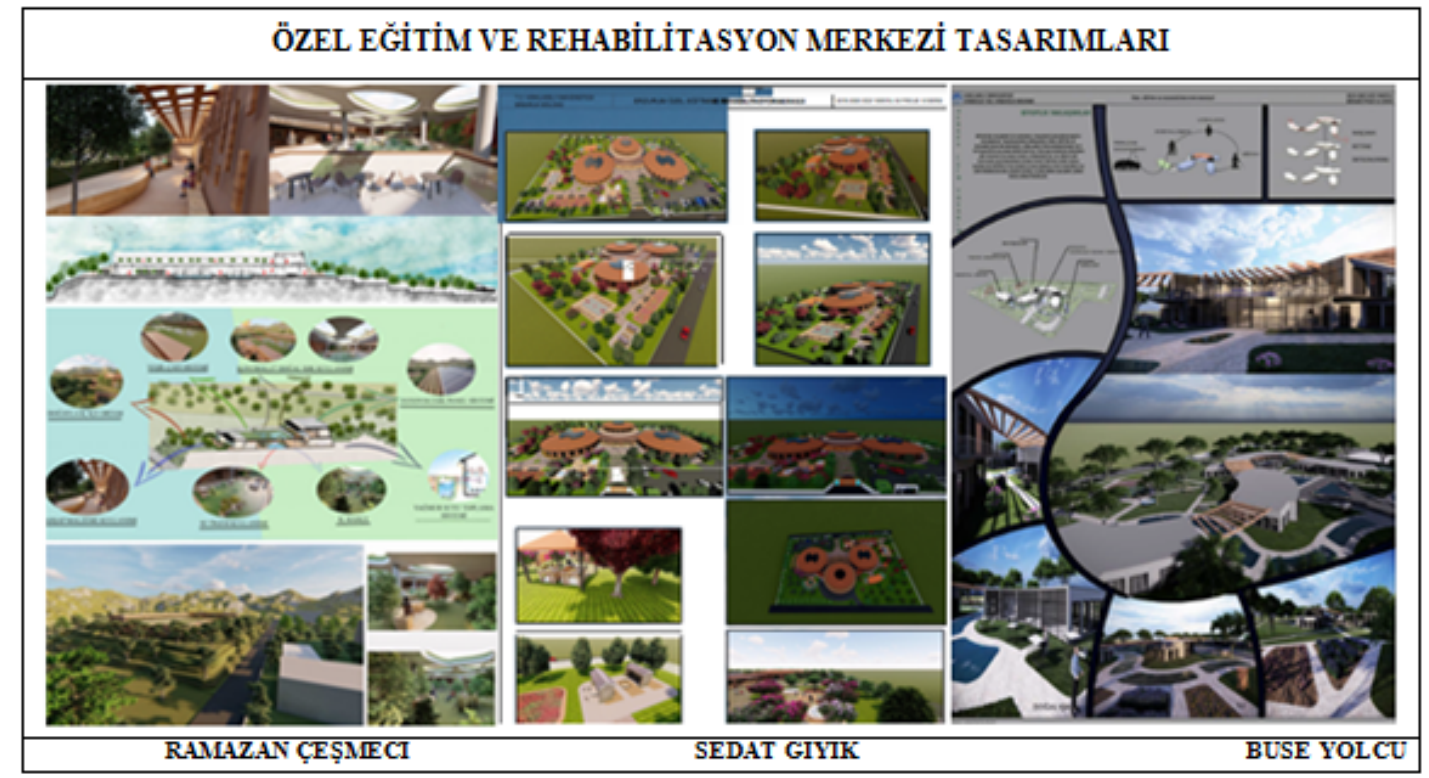


Tablo 6. Atölye kapsamında üretilen Sosyal Yaşam Merkezi Tasarımları

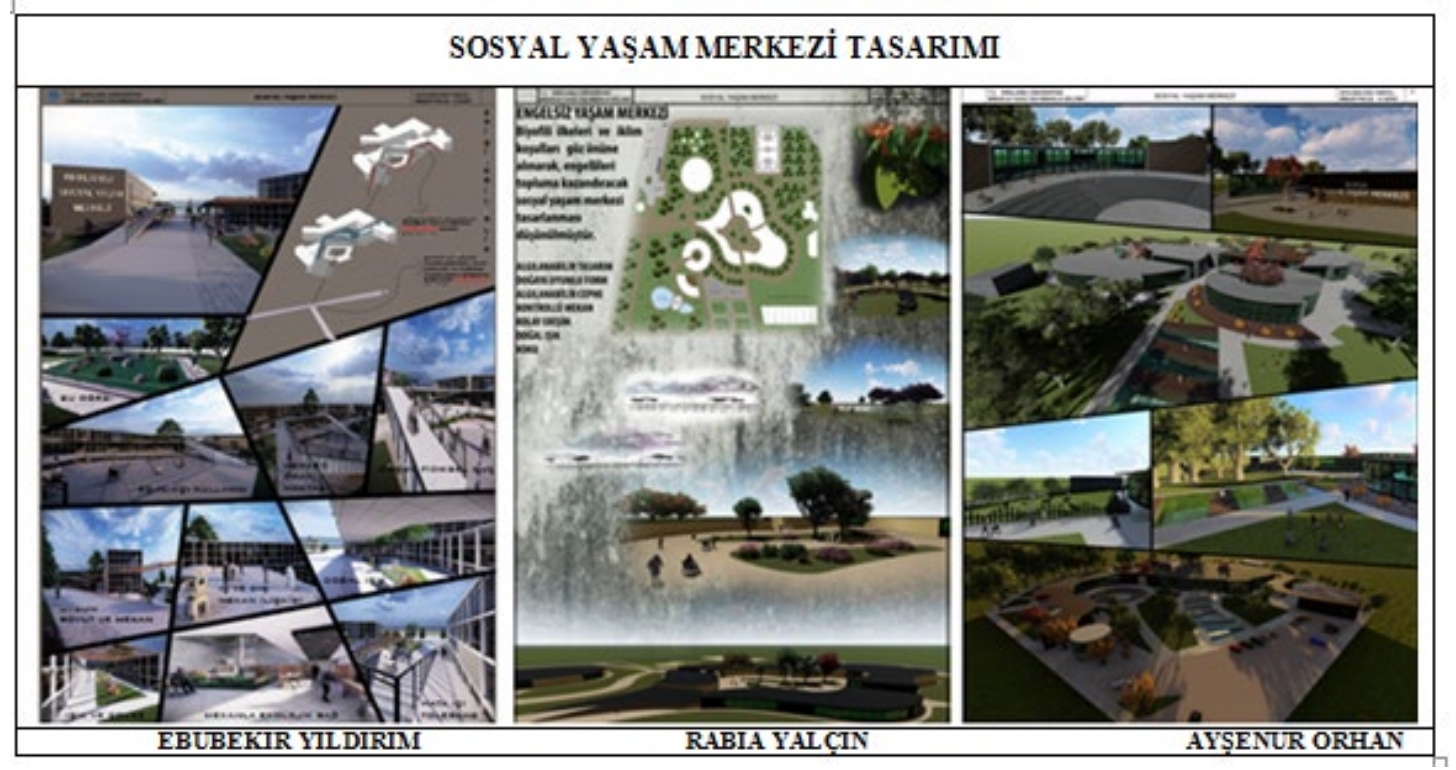

Tablo 7. Atölye kapsamında üretilen tasarımlar

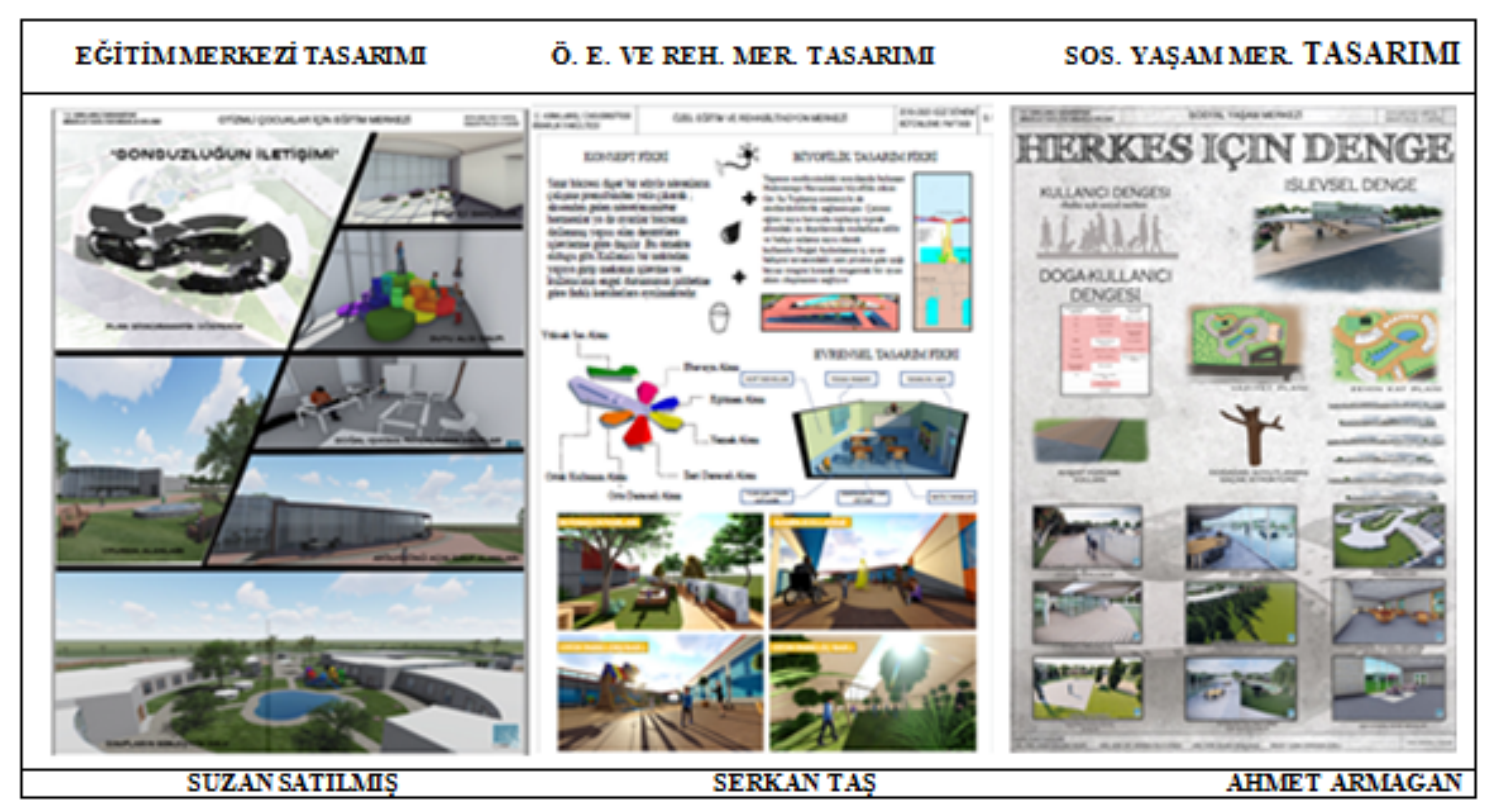

\subsubsection{Doğanın Doğrudan Deneyimlenmesi}

Öğrenciler insan-doğa-mekân ilişkisinin kurgulanmasında, daha çok doğanın doğrudan deneyimlenmesine önem vermişlerdir. Öncelikle arazi seçimlerinde; arazi ve çevresinde doğal öğelerin varlığı dikkate alınmış, manzara öğesi olarak yeşil alanlara veya suya yakın olmak tercih edilmiştir. Bazı öğrenciler, kentin dış çeperlerinde doğal alanlarla daha ilişkili ve daha sakin alanları tercih etmişlerdir.

Eğitim Merkezi tasarlayan Ahmet Furkan Tırpan, tasarım konseptini oluştururken otizmli çocukların/bireylerin sosyal yaşamdan soyutlandığını düşünerek yapının, bulunduğu kent ile uyum içinde olmasını ve kentli için de uğrak bir nokta olmasını hedeflemiştir. Çocukların her gün bu eğitim merkezine geldiklerini de göz önünde bulundurarak, arazi seçiminde kent içinde olmayı tercih etmiştir. Öğrenci, biyofilik tasarım gereği de, öğrencilerin arazinin yakın çevresinde doğal unsurlar ile ilişki kurabilmesi ve gerektiğinde doğayı deneyimleyebilmesi öngörüsünden yola çıkarak park, yeşil 
alan ve deniz ile bağlantı kurabilecek bir yer seçmiştir. Arazinin girişinin sağlandığı Fatih Caddesinin, insanların yoğun olarak kullandığı sosyal yaşam alanlarının bulunduğu bir aks olması tasarımı yönlendiren bir karar olmuştur. Tasarımda da, caddeye yakın yerlerde, sosyal yaşamın devamı niteliğinde ailelerin de bulunabileceği ayrıca, otizmli öğrencilerin de çalışabileceği bir kafe, bir oyun parkı ve otizmle ilgili farkındalık oluşturacak panoların da yer aldığı oturma mekânı konumlandırılmıştır. Bu yaklaşım, kamusal alan ve çocuklar için özel alan olan eğitim mekânları arasında geçişi kolaylaştıran bir ortam yaratmıştır (Şekil 1).

Özel Eğitim ve Rehabilitasyon Merkezi tasarlayan Ramazan Çeşmeci ise tasarım konseptini oluştururken, kullanıcıların kısıtlı zaman aralığında bulunacakları bu merkezde doğayla iç içe, güvenli ve kentten izole bir ortamda bulunmalarını hedeflemiştir. Kullanıcı grubunun gereksinimlerinden dolayı yapının şehir merkezine çok uzak olmaması gerektiğinden kentin çok da dışında olmayan bu araziyi seçmiştir. Yol kotundan 7 metre yükseklikte yer alan ve tüm çevreye hâkim olacak şekilde konumlanmış arazide öğrenci, biyofilik tasarım gereği doğal unsurlar ile ilişkiyi kendisi kurgulamıştır. Yap1, arazide en tepede düz olan bölüme yerleştirilmiştir. Konsept gereği, hem kapalı hem de açı mekânlarda, kullanıcıya doğanın içinde oldukları hissettirilmek istenmiş̧ir. Arazide eğimin daha az olduğu noktadan yaya ve araç girişleri düzenlenmiştir. Yaya olarak gelenler, farklı kotlarda oluşturulmuş bahçelerin arasında oluşturulan rampayı kullanabilirken, araç ile gelenler ise iki tarafı ağaçlarla çevrelenmiş yoldan yapıya ulaşabilmekte ve doğayı doğrudan deneyimleyebilmektedirler (Şekil 2).
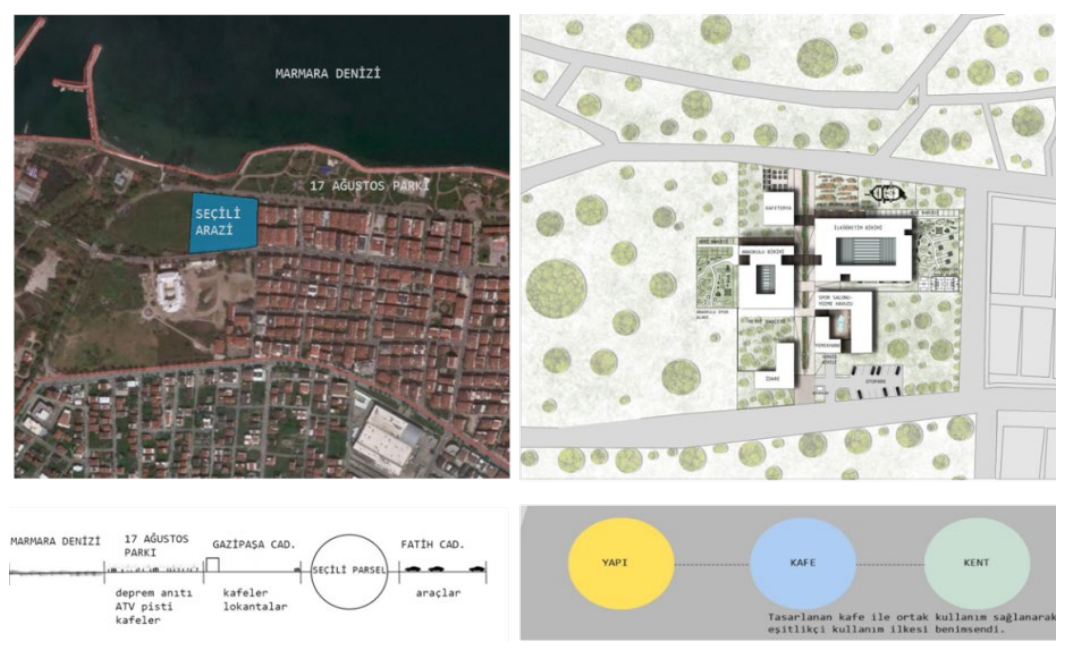

Şekil 1. Ahmet Furkan Tırpan'ın arazi seçim kararları ve tasarım yaklaşımı

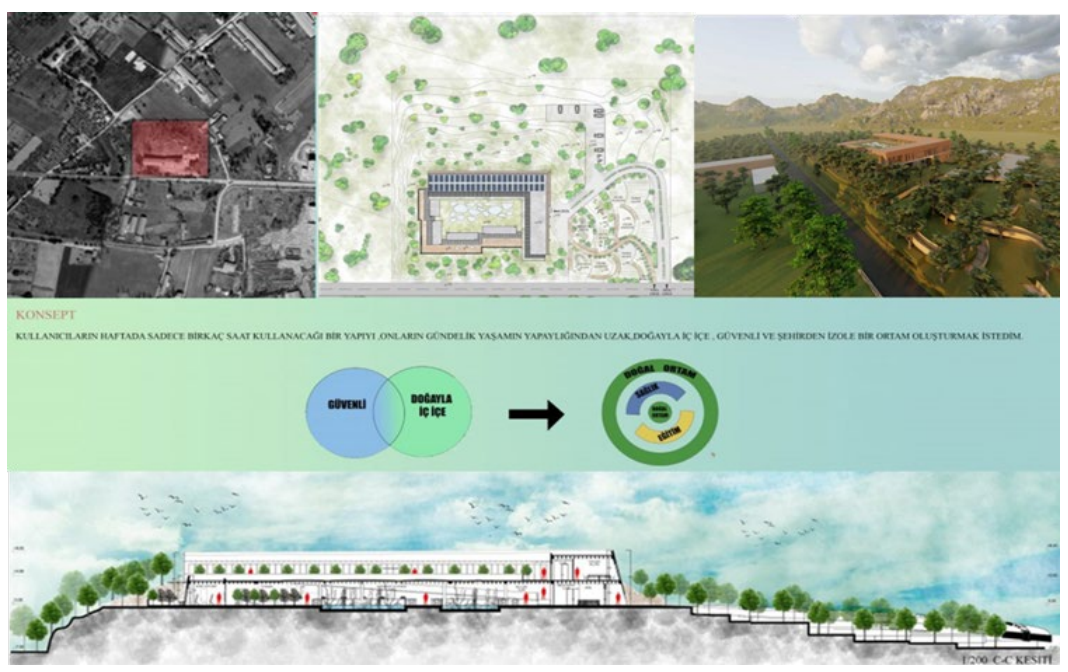

Şekil 2. Ramazan Çeşmeci'nin arazi seçim kararları ve tasarım yaklaşımı 
Doğanın doğrudan deneyimlenmesinde, gün ışığını etkin kullanma, doğal havalandırma ile mekândaki 1sı konforunu kontrol edebilmek önemlidir. Ancak otizmli çocuklar/bireyler genellikle çeşitli ışık, sıcaklık, ses ve koku gibi durumlara karşı farklı hassasiyetlere sahiptirler. Bu nedenle öğrenci tasarımlarında, konfor koşullarının bireylere uygun olarak ayarlanması gerekli olmuştur. Tasarımlarda aydınlatma ve havalandırmanın doğal yöntemlerle sağlanmasına özen gösterilmiş, duvar ve çatıda bırakılan boşluklardan otizmli çocukları rahatsız etmeyecek şekilde gün ışı̆̆ alımı sağlanmıştır. Bireylerin aşırı durumlardan olumsuz etkilenmemeleri için gerektiğinde cephede ve çatıda güneş kırıcılar düzenlenmiştir.

Ahmet Furkan Tırpan ve Ramazan Çeşmeci, dikdörtgen biçimli bina kütlelerine sahip tasarımlarında mekânlarını cepheye yerleştirmişler ve mekânların hepsinin doğal aydınlatma ve havalandırmadan yararlanmalarını sağlamışlardır. Orta mekânlarda yer alan etkinlik, oturma, oyun ve süs havuzu alanlarının aydınlatılması için tepeden aydınlatmayı kullanmışlardır. Mekânın işlevine göre boyutları değişen pencereleri, cephede ve çatıda düzenlerken güneş korunumu sağlamak için ahşap güneş kırıcılardan yararlanmıştır (Şekil 3, Şekil 4).
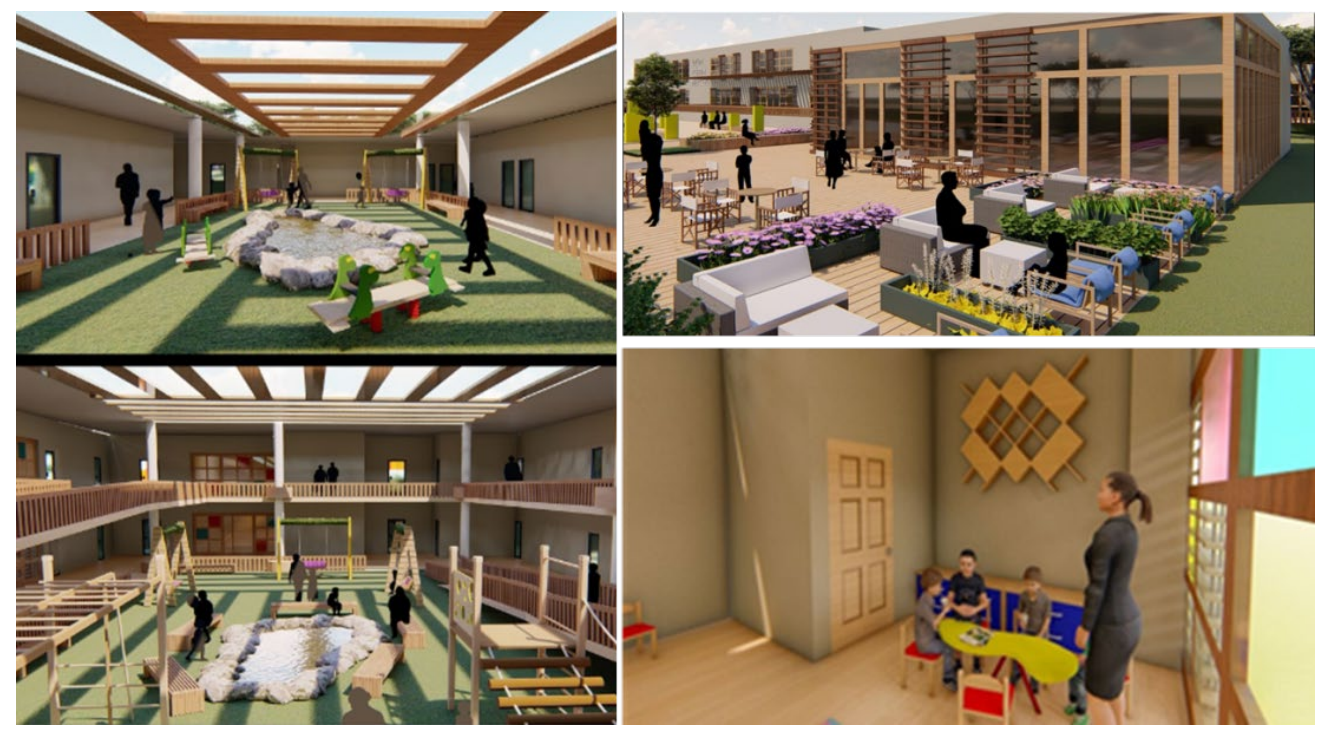

Şekil 3. Ahmet Furkan Tırpan'ın doğal aydınlatma konusunda tasarım kararları
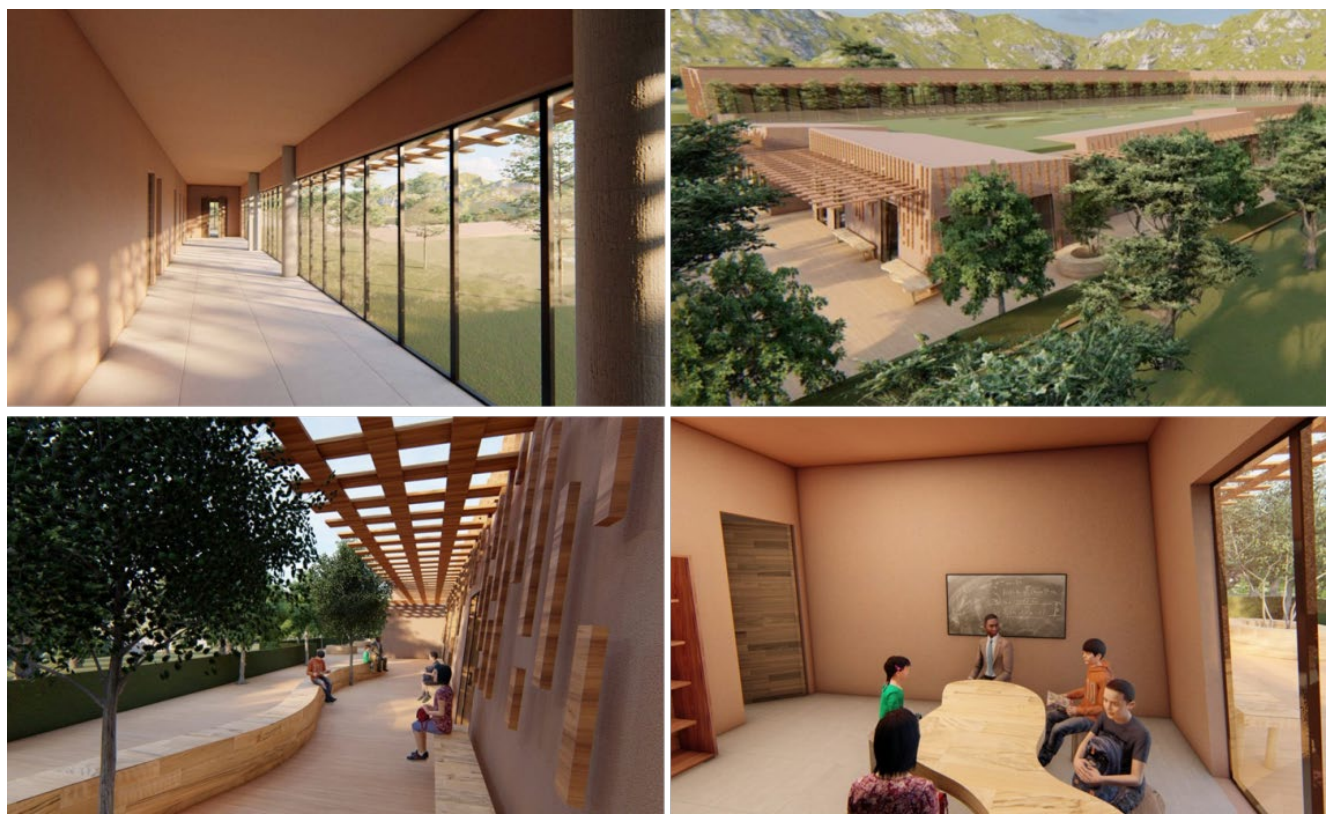

Şekil 4. Ramazan Çeşmeci’nin doğal aydınlatma konusunda tasarım kararları 
Doğrudan deneyimlemede insan-doğa ilişkisini en çok güçlendiren unsur, (Day, 2004)'in da belirttiği gibi, yaşayan bitkiler ve ağaçlardır. İç mekânın bitkilendirilmesi, ortama yumuşaklık, hayat ve ritim katması bakımından önemlidir. İnsanın bitki kokularını günlük olarak algılamasına ek olarak su ile görsel temas gibi doğal ortam özelliklerine maruz kalması da insan sağlığının ve yaşam kalitesinin iyileşmesine neden olmaktadır (Bloom, 2013). Bancroft Mount Laurel Kampüsünü tasarlayan mimar Merilee Meacock suyun doğada büyük bir rol oynadığını, tüm insanlarda ve özellikle de otizmli öğrencilere çok iyi geldiğini belirtmektedir. Tasarlanan kampüste otizmli bireylerin suyun sesini ve hissini sevdiklerini, içinde oynamaya, suyun sıçramasına bayıldıklarını ifade etmektedir (School Construction News, 2021).

Alıntılarda da yer verildiği üzere, sözü edilen özelliklerden dolayı öğrenciler, en çok sözü edilen bu öğeleri tasarım ile ilişkilendirmeye çalışmışlardır. Bitkilere ağılıklı olarak dış mekânda yer verilmiştir. Ayrıca kapalı mekânlarda, iç bahçelerde ve yeşil duvar uygulamalarında da bitkiler kullanılmıştır. Öğrenciler yaptıkları araştırmalar doğrultusunda otizmliler için iyileştirme bahçelerinin (Ayaz, 2019) ve duyu bahçelerinin (Şensoy, 2017) önemli olduğunu tespit ederek bitkilerin tüm duyularını harekete geçirecek şekilde farklı kullanımlarına dikkat etmişlerdir. Özellikle peyzaj tasarımında, renkli çiçekli bitkileri tercih etmişlerdir. Öğrenciler biyofilik tasarım çerçevesinde sözü edilen şekillerde bitki kullanımına ağırlık verirken, tasarımda çevresel özellikler bakımından bitki ve ağaçların rüzgârı ve güneşi kesme gibi işlevsel özelliklerini kullanımlarını arka planda bırakmışlardır. Tasarımda bazı öğrenciler su öğesini manzara olarak kullanırken, çoğu öğrenci de suyun sesinden, görüntüsünden yararlandırmayı ve rahatlatmayı amaçlamışlardır. Ayrıca, iç mekânda, seçilen konunun özelliğine bağlı olarak tedavi amaçlı havuzlar tasarlanmışlardır.

Ahmet Furkan, tasarımının ana kurgusunu yeşil koridor olarak düzenlediği doğrusal bir aks çevresinde oluşturmuştur. $\mathrm{Bu}$ aksın ortasında ağaçlarla ve renkli çiçeklerle desteklemiş olduğu oturma elemanları ile yolu ikiye bölmüştür. Ayrıca aks üzerindeki bina cephelerinin sağır duvarlarında yeşil duvarlar uygulamıştır. İç mekânda ortak alanlarda ve kütlelerin arasında kalan iç avlularda su öğesine yer vermiştir (Şekil 5). Ramazan Çeşmeci ise tasarımının zemin katında, giriş aksında düzenlediği ortak alanda, bitki ve su öğesiyle desteklediği yoğun bir doğal ortam yaratmıștır. Bu doğal alanların içinde ve etrafinda oturma, dinlenme, bekleme gibi eylemlerin ve farklı etkinliklerin gerçekleştirilmesine imkân tanımıştır. Havuzlarda çeşitli su bitkilerine ve canlılarına yer vermiştir. Aynı zamanda bu katın çatısında yeşil çatı uygulamasını kullanmıştır. Dış mekânda yoldan bina girişine kadar olan eğimli bölümde kademelenmiş çiçek bahçeleri oluşturmuştur. Bina çevresinde ve arazide yoğun bir ağaçlandırma yaparak bir koru, orman etkisi yaratmaya çalışmıştır (Şekil 6). Bu yönleri ile öğrenciler, tasarımlarının kapalı ve açık mekânlarda kurgulanan tüm dolaşım akslarında doğanın elemanlarına yer vererek kullanıcılarının sürekli olarak doğaya maruz kalmalarını sağlanmışlardır.

\section{YEȘIL KORİDOR}

Ana aksa sirkülasyon ișlevinden bașka ișlevler de ekleyerek yașayan bir mekan haline getirildi. Oturma elemanları,yeșil duvarlar ve çeșitli peyzaj elemanları bu aksa eklendi.
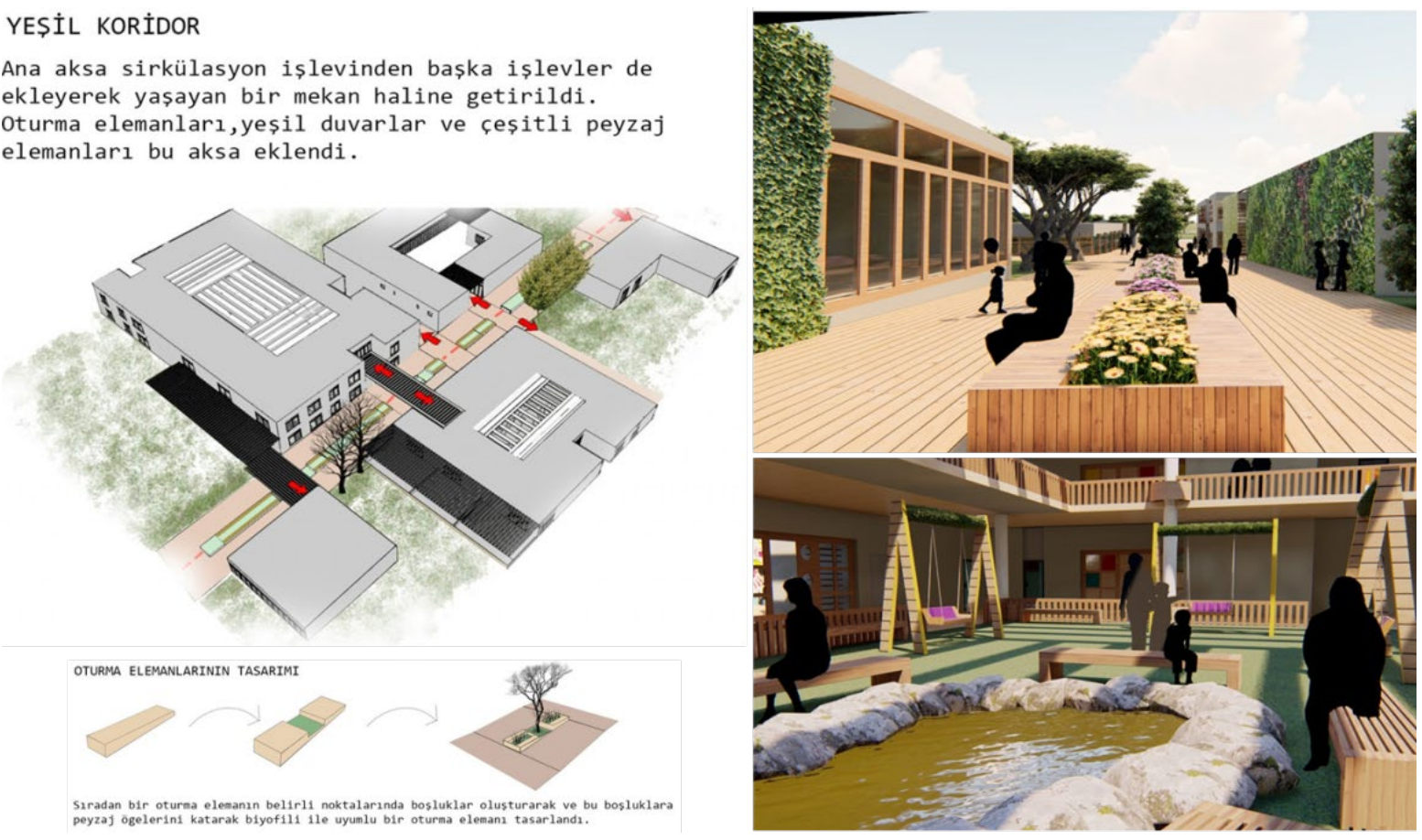

Şekil 5. Ahmet Furkan'ın tasarımında bitki ve su kullanımına dair kararları 


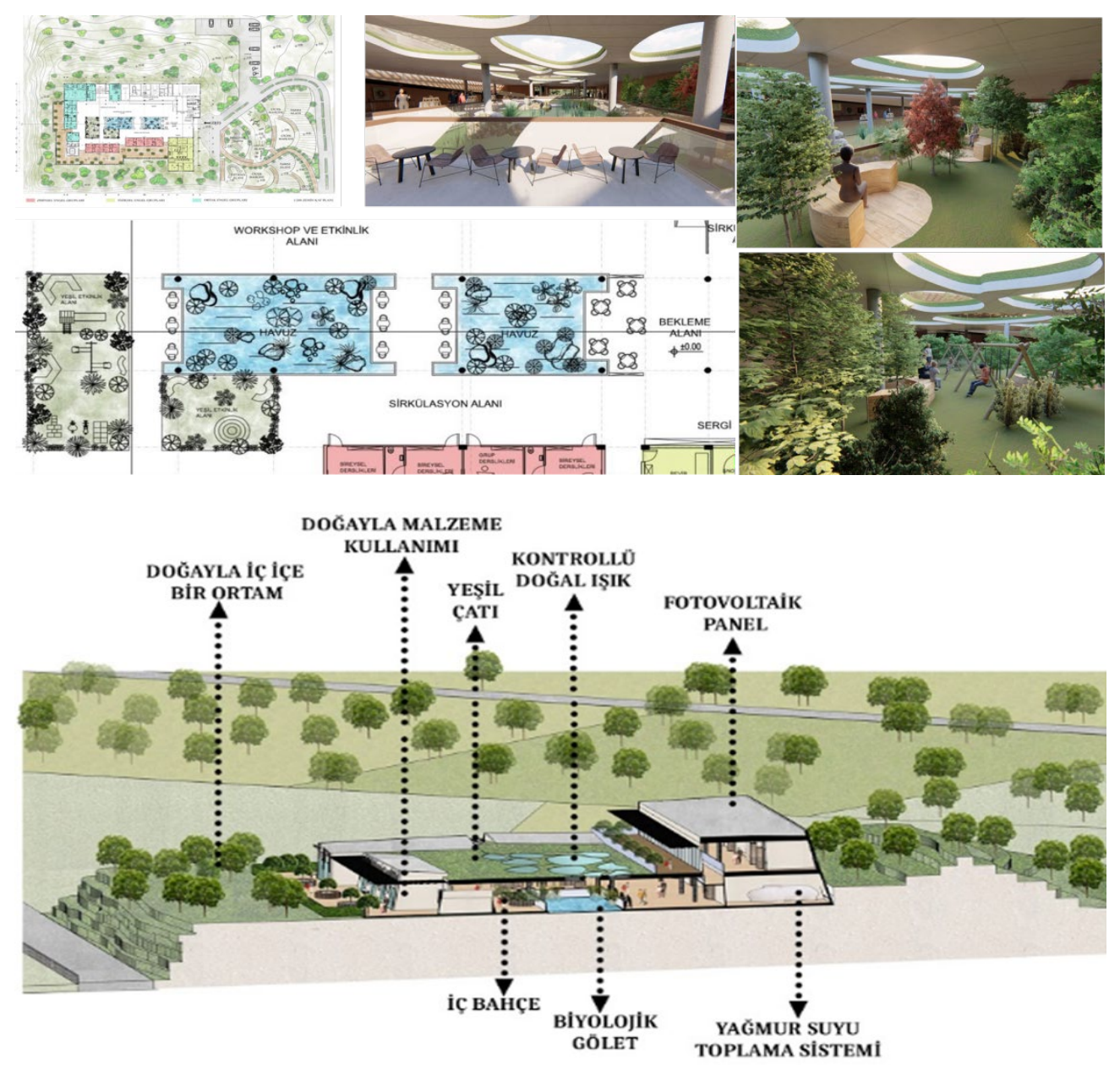

Şekil 6. Ramazan Çeşmeci'nin tasarımında bitki ve su kullanımına dair kararları

Biyofili hipotezine göre, insanların doğaya ve hayvanlara olan yakınlığı ve hayvanlara bakmak için doğuştan gelen bir ilgisi vardır (Wilson, 1984). Bu yaklaşımla hayvanlar, günümüzde otizm veya diğer nörogelişimsel bozuklukları, psikiyatrik, sosyal nitelikte sorunları olan insanlar için tedavilerinin bir parçası olarak kullanılmakta, sağlanılan faydalar pek çok çalışma ile ortaya konmaktadır (Martin ve Farnum, 2002; Thodberg vd., 2021; Sams vd., 2006; Bass vd., 2009; Muslu ve Conk, 2011; Byström vd., 2019). Bu yönleriyle kapalı ve açık mekânlarda hayvanlara yer vermek ve çocukların kontrollü bir şekilde doğrudan temasını sağlamak olumlu karşılanmaktadır. Öğrenciler, bitki ve su kullanımı kadar olmasa da tasarımlarında hayvanlara yer vermeyi uygun bulmuşlardır. Çoğunlukla açık mekânlarda at binme yerleri (Şekil 7) düzenlenirken bazı öğrenciler de kuşlar ve evcil hayvanlar için mekânlar oluşturmuşlardır.
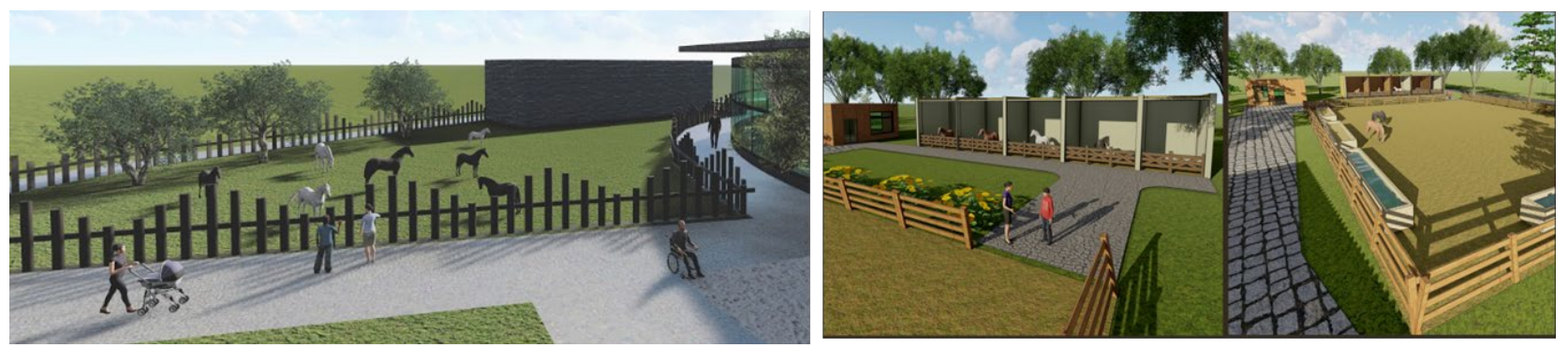

Şekil 7. Öğrencilerin tasarımlarında yer verdikleri at binme mekânları 
Ayrıca, arazinin mevcut yapısı korunarak iklimle uyumlu peyzaj düzenlemelerine yer verilmiştir. Ateş öğesinin kullanımına ise hiçbir öğrenci yer vermemiştir. Bu durumun kullanıcıların özel durumuna bağlı olarak güvenlik kaynaklı olduğu düşünülmektedir.

\subsubsection{Doğanın Dolaylı Deneyimlenmesi}

İç mekânda bitkilerin mekâna sokulamadığı durumlarda mekânı peyzaja döndürmek, mümkün olan en geniş manzara görüntüsünü, mekânın kullanıcılarına sunabilmek (Demirbaş ve Demirbaş, 2019), iç mekândan doğanın dolaylı deneyimlenmesine imkân tanımaktadır. Böyle bir görüş, kullanıcıları doğaya yöneltmekte ve onları sürekli olarak performanslarını artıran sağlıklı bir görüşe bağlamaktadır. Bu kapsamda, öğrencilerin neredeyse hepsi, iç mekânda bitki kullanımına yer verseler de vermeseler de, doğayla görsel bağlantıyı artırmak üzere tasarımlarında pencere boyutlarını büyük düşünmüşlerdir.

Doğanın dolaylı deneyimlenmesinde genel olarak doğa, temsili veya sembolik olarak tasarıma aktarılmaktadır. Öğrencilerin en tercih ettiği uygulamalar doğanın formlarının, geometrilerinin, doğal malzeme ve renklerin kullanımı olmuştur. Biçim, görsel uyarıcılığı ve yenilik, farklılık, önceden görülmemişlik gibi değerler taşıyan mesajları bakımından hem kuramsal anlamda hem de uygulamada mimari için önemli bir konudur (Çırak, 2008). Doğada eğrisel, fraktal ve biyomorfik biçimlenişler bulunmaktadır (Minsolmaz Yeler, 2012). Doğadan ilham alınmış formların eğrisel, yumuşak ve akışkan özellikte olmaları ve doğayı hatırlatmaları biyofilik duyguyu güçlendirmekte (Kellert, 2008), insanlarda olumlu duygusal tepkiler ve sicaklık üretebilmektedirler (Kumar vd., 2020). Biyomorfik mimarlı̆̆ın örnekleri, canlı organizmaların (bitkiler, hayvanlar vb.) yapay taklitlerini ve daha fazlası olarak da doğal dünyada karşılaşılan strüktürel özellikleri yansıtan zekice yapılmış benzetimleri içermektedir (Joye, 2007). Bu kapsamda doğa ile ilişki kurmada öğrencilerin en aktif olduğu konu kütle biçimlenişi olmuştur. Öğrenciler, sözü edildiği gibi, çoğunlukla eğrisel, akışkan formları tercih etmişlerdir. Birkaç öğrenci de, biçimlenişte ağaçların dallarına benzer strüktürler ve sütunlar kullanmışlardır. Ayrıca, iç mekânlarda yaratılan eğrisel yüzeyler, daha düzgün bir dolaşıma imkân vermek, kör köşeler yaratmamak ve güvenlik sorunları oluşturmamak bakımından otizmlilerin özel durumları dikkate alınarak tercih edilmiştir (Tablo 3, 4, 5, 6, 7).

Yapılı çevrede yerel ve doğal malzemeler kullanmak, mekânı deneyimleyen insanların doğa ile bağlantısını kuvvetlendiren temel unsurlardandır (Genç vd., 2018). Malzemelerin doğadan yapıya dönüşümü, olumlu görsel ve dokunsal tepkileri uyarmaktadır (Kellert ve Calabrese, 2015). Öğrenciler modern yapım sistemlerini tercih etmiş olmakla birlikte iç mekânda duvar ve zemin döşemelerinde, mobilyalarda, cephelerde ve dış mekânda yarı açık mekânların zeminlerinde ahşap malzeme kullanımına ağırlık vermişlerdir. Ahşap malzeme doğal görünümü yanında kaza olasılığını azaltmak bakımından da tercih sebebi olmuştur.

Öğrenciler, otizmlilerin renk konusundaki davranışlarını çok araştırmamakla birlikte biyofilik tasarımın genel yaklaşımından yola çıkarak renk kullanımına karar vermişlerdir. Mekânların işlevine bağlı olarak gerektiğinde öğrencileri uyarmak, yaratıcılıklarını ve motivasyonlarını artırmak ve gerektiğinde de sakinleştirmek için su, gökyüzü, güneş, bitki, toprak gibi doğanın renklerinin pastel tonları tercih etmişlerdir. Cephelerde ise daha çok ahşap malzeme kullanımına bağlı olarak kahve tonları ve açık renkler kullanılmıştır (Şekil 3, 4, 5, 6).

Öğrenciler, doğanın dolaylı olarak deneyimlenmesinde yer verilen doğayı çağrıștırma, bilgi zenginliği, zamanın değişimi gibi diğer nitelikler üzerinde ise çok fazla tasarım fikri üretmemişlerdir. Bu niteliklerin, öğrenciler tarafından tam kavranamadığı düşünülmektedir.

\subsubsection{Mekân ve Yer Deneyimi}

Gözetleme (prospect), insanların uzak mesafedeki güzel görünümleri ve tehlikenin algılamasına olanak verirken; sığınma (refuge), insanlara güvenli ve emniyetli alanlar sunmaktadır. Bu biyofilik hedef, dış manzarayla iç mekânlar arasında görsel bağlantılar kurulması, güvenli ve korunaklı mekânlar oluşturulması gibi tasarım stratejileri ile sağlanabilmektedir (Kellert ve Calabrese, 2015). Otizmliler için yapılacak tasarımlarda güvenlik, en önemli konu olmaktadır. Shahmahommadian ve Shahmahommadian (2020), çocukların fiziksel güvenliğinin kapalı alanlarda sağlanmasının daha garantili olduğunu ve doğa ile etkileşim içinde olan ve eğitmenlerin kontrolünde olabilecek güvenli bir yapı tasarlamanın oldukça zor göründüğüne dikkat çekmektedir. Ancak, örnekler incelendiğinde, Meacock (School Construction News, 2021)'un kampüs tasarımında olduğu gibi, doğru bir tasarım ile güvenlik sorununa çözüm üretilebileceği görülmektedir. Öğrenciler, kullanıcı grubunu göz önünde bulundurarak yer seçiminde hem arazi içerisinde iç mekân ve dış mekân kurgusunun oluşturulmasında hem de arazinin çevresi ile ilişkilerinde özellikle bu ilkelere dikkat etmişlerdir. Öğrencilerin çoğunluğu, otizmliler için güvenli olması bakımından daha çok düz arazi tercih 
etmişlerdir. Eğimli arazide çalışan öğrenciler ise güvenlik koşullarını almaya çalışarak korunaklı mekânlar yaratmaya çalışmışlardır. Ancak, güvenlik, atölye ortamında çok tartışılan kavram olmasına rağmen alınan kararlar daha çok sözde kalıp tüm projelere yansıması yeterli olmamıştır.

Öğrenciler, tasarımlarının mekân düzenlemelerinde, seçilen konuya bağlı olarak, otizmliler için mekân kurguları değişkenlik ve çeşitlilik göstermesine rağmen, mekânlar arasında dengeli bir dağılım kurmaya çalışmışlardır. Parça ve bütün ilişkisi kapsamında; mekânların birbirleri ile aynı zamanda bütünü arasında, farklı kütlelerden oluşan tasarımlarda kütle ve bütün arasındaki kurulan bağlantılar ortalama düzeyde sağlanmıştır. Geçiş mekânlarının doğru kurgulanması otizmliler için de çok önemlidirler. Çünkü otizmli bireyler için farklı görevler arasında ani geçişlerin olduğu bir ortama sahip olmak (örneğin bir aktiviteden diğerine geçiş) rahatsız edici ve üzücü olabilmektedir. Bu nedenle, çeşitli mekânlar arasında kolay bir geçişin sağlanması (Mostafa, 2008) istenmektedir. Öğrenciler tasarımlarında da geçiş mekânlarını daha çok kapalı ve açık mekânlar arasında bağlantıyı sağlayan mekânlar olarak kurgulamışlardır. Kapalı mekânlarda ise öngörülen geçişlerin nasıl sağlanacağını tam anlamıyla kavrayamamışlardır. Otizmliler için tasarımların ana hedefi, çocukların/bireylerin bağımsız hareket edebilecekleri düzenlemelerin yapılmasıdır. Bu nedenle öğrenciler hem mekân içinde dolaşım alanlarında hem de mekân dışında tüm alanda basit, kolaylıkla algılanabilir yön bulmaya yönelik çözümler üretmeye çalışmışlardır. Bazı öğrenciler, eğrisel yollar ve belirgin akslar oluşturarak bilinçli bir yönlendirme sağlarken bazıları da kolay algılanamayan giriş-çıkışlar nedeniyle tasarımda karışıklığa sebep olmuşlardır. Yerel, kültürel ve ekolojik bağlılık konusunda öğrenciler, tüm tasarımlarında olduğu gibi yerin koşullarına bağlı olarak yerel peyzaj, yerli bitki örtüsü, topoğrafya, iklim koşulları, manzara gibi konuları tasarımla ilişkilendirme konusunda sorun yaşamazken, yerin kültürel değerlerini yansıtma konusunda yetersiz kalmışlardır.

Öğrenciler, evrensel tasarım ilkeleri kapsamında otizmliler için basit, algılanabilir yön bulma çözümlerinin yanı sıra tüm mekânların herkes tarafından, zorlanmadan, eşit kullanılmasına da özen göstermişlerdir. Özellikle, iç mekân ve dış mekânların dolaşım alanlarında kot farklarının olduğu yerlerde bağımsız hareket edebilmelerine imkan tanımak için merdiven ve asansörlere alternatif olarak rampalı dolaşımlar düzenlemiş̧lerdir. Ancak, bazı öğrenciler, otizmlilerle birlikte farklı engel durumlarına sahip kullanıcıların da bulunduğu rehabilitasyon merkezi ve sosyal yaşam merkezi tasarımlarında, herkesi kapsayacak çözümler üretme konusunda zorlanmışlar ve yetersiz kalmışlardır. Bu çalışmalarda üretilen çözümler rampa ve engelli tuvaleti uygulamasının ötesine geçememiştir.

\section{3. Öğrenci Yorumlarının Değerlendirilmesi}

Atölye sürecinin başlangıcında, araştırma aşamasında yapılan yerinde yapılan gözlemler ve sözlü görüşmeler sonrasında öğrencilerin yaptıkları yorumlarından birkaçı şöyledir:

"Önceden araştırdığımız kullanıcı gruplarını birebir derse girip yerinde görme şansımız oldu. Çocukların özel gereksinimleri hakkında daha net fikirlerim oluştu." (SY)

"Tasarımlarımızda evrensel mimari ilkelere uygun tasarım anlayışını esas alırken mekânları, kullanıcı davranışlarını ve yaşanılan sorunları yerinde incelemenin ne kadar önemli olduğunu, engelli diye sınıflandırdığımız bireyler için aslında engeli bizim oluşturduğumuzu ve mekânsal olarak yeterli konforu sağlayamadığımızı fark ettim.” (RY)

"Özel eğitim gerektiren bireylerin özel bir binada eğitim görmeleri onların en büyük haklarıdır. Mekânların kullanımı kötü olmasına rağmen içerideki eğitmenlerin özel ilgi ve çabası, merkezin iyi bir eğitim yuvasına dönüşmesini sağlamıştır.” (BY)

"Ben de bir mimar adayı olarak üstümde var olan sorumluluğu hissettim. Eğer amacına uygun olarak bir tasarım yapamazsam bunun kötü sonuçlar doğurabileceğini fark ettim. Sadece tek bir kullanıcı grubunu düşünerek değil, tüm kullanıcı gruplarına hitap edecek tasarımlar yapmam gerektiğini anladım. 'Herkes İçin Tasarım" kavramının farkına varmış oldum.” (GE)

Yerinde yapılan gözlemler sonrasında yapılan yorumlardan, öğrencilerin aşağıdaki kazanımları elde ettikleri tespit edilmiştir:

- Özel gereksinimi olan bireylerin ihtiyaçlarının ve davranışlarının anlaşılması,

- Otizmlilerin ve ailelerinin yaşadıkları zorlukların anlaşılması,

- Otizmliler için tasarımda neler yapılabileceğinin kavranması,

- Evrensel tasarım ilkelerinin ve tasarımda nasıl kullanılacağının kavranması,

- Tasarım sürecinde engelliler konusunda empati kurulabilmesi, 
"Biyofili" ve "biyofilik tasarım" kavramlarını daha önce duymadıklarını ifade eden öğrencilerin çoğu, verilen seminerler, karşılıklı tartışmalar ve öğrencilerin kendi araştırmaları ile konuyu pekiştirdiklerini ve tasarımda kullanılabilir hale getirdiklerini dile getirmişlerdir.

Tasarım sürecinde biyofilik tasarımın uygulanması sonrasında yapılan yorumlardan, öğrencilerin aşağıdaki kazanımları elde ettikleri tespit edilmiştir:

- Doğanın çok yönlü faydalar sağladığının anlaşılması,

- Doğanın otizmliler üzerinde iyileştirici etkisinin olduğunun anlaşılması.

- Otizm-doğa-mekân-tasarım arasındaki ilişkinin kavranması,

- Biyofili ve biyofilik tasarım kavramlarının anlaşılması,

- Mekânların doğa ile (biyofilik tasarım deneyimleri ve nitelikleri) nasıl ilişkilendirileceğinin anlaşılması.

Öğrenciler, ayrıca, farklı tasarım yaklaşımları ile daha önce ele almadıkları bir kullanıcı grubuna göre tasarımlarını geliştirmelerinin; farklı bakış açıları kazanmalarında, problem çözme yeteneklerinin gelişiminde, özgün fikirler üreterek yaratıcılıklarının gelişiminde katkılar sağladığını, eğitimlerinde ve meslek hayatlarında bu yaklaşımlarını kullanacaklarını da belirtmişlerdir.

Atölye sürecinde genel olarak karşılaşılan zorluklar konusunda, öğrenciler şu konulara dikkat çekmişlerdir:

- Bir projede aynı anda, daha önce deneyimlenmeyen iki (otizmliler ve biyofili) konuya yer verilmesi,

- Otizmli bireylerin davranışlarının ve ihtiyaçlarının yeterince kavranamaması,

- Otizm ve biyofilik tasarım arasındaki ilişkinin yeterince kavranamaması,

- Biyofilik tasarım ilkelerini anlama ve tasarıma aktarmada yetersiz kalınması,

- Doğanın iç mekânda nasıl kullanılacağının kavranamaması,

- Proje kapsamının geniş olması ve zamanın yeterli olmaması,

- Kapsamlı araştırmaların yapılamaması.

Öğrencilerin çoğu, yukarıda sözü edilen kazanımları elde etmelerine rağmen proje konusunun geniş tutulması ve zamanın yeterli gelmemesi konusunda zorlandıklarını ifade etmişlerdir. Zaman konusuna bağlı olarak, tasarım sürecinde öğrencilerin daha çok biyofilik tasarım deneyim ve niteliklerini kavramada ve uygulamada zaman harcadıkları, iç mekân çözümlerinde ise otizmlilere yönelik diğer tasarım ilkelerinin uygulanmasında yetersiz kaldıkları yürütücüler tarafından da tespit edilmiştir. Kapsam ve zaman konusuna benzer bir eleştiri, Kayıhan ve arkadaşları (2020)'nın, biyofilik tasarım konusunu ele aldıkları stüdyo sürecinde de dile getirilmiştir. Bu yönleriyle, belirlenen hedeflere ulaşma konusunda, kapsam ve zaman konularının tekrar değerlendirilmesi gerekliliği ortadadır. Her öğrencinin atölye sürecine katılımı ve ilgisi aynı olmadığından diğer konularda zorlukların yaşanması ise normal karşılanmıştır.

\section{SONUÇ}

Tüm atölye süreci genel olarak değerlendirildiğinde, süreç boyunca verilen teorik bilgilerin, yerinde yapılan incelemelerin, uzmanların verdiği bilgilerin ve öğrencilerin kendi araştırmalarının sonuç ürünlere beklenen ölçüde aktarıldığı görülmüştür. Sözü edilen çalışmaların, mimarlık öğrencilerinin özel durumları olan kullanıcı gruplarının ihtiyaçlarını anlamaları, empati kurmaları, farkındalıklarını artırmaları, biyofilik tasarım ve evrensel tasarım ilkeleri çerçevesinde herkesi kapsayacak şekilde tasarımlar geliştirmeleri konusunda katkı sağladığı tespit edilmiştir. Bu kapsamda, çok da üzerinde durulmayan bu tür konuların mimarlık eğitiminin bir parçası olması için özel bir çaba harcanması gerektiği düşünülmektedir. Ancak, gelecekte, yeni atölye süreçlerinde öğrencilerin dikkat çektiği zorluklara karşı farklı önerilerin geliştirilmesi gerekliliği de kaçınılmazdır. Bu bilinçle yetişen öğrencilerin; topluma faydalı, insan ihtiyaçlarını önemseyen ve sorunlara çözümler üreten, sosyal farkındalı̆̆ı yüksek bir mimarlık anlayışının oluşmasına katkı sağlayacağı ortadadır. Bu çalışmada olduğu gibi, mimarlık ortamında atölye sürecinde öğrencilerin deneyimlerinin akademik çalışmalarla paylaşılması, özel kullanıcı gruplarına ait tasarım çözümleri üretme konusunda farkındalığı artıracaktır. Ayrıca, üretilen tasarım çözümlerinin, çalışmada olduğu gibi sergileme yöntemi ile kentlilerle paylaşılması farkındalığın çok yönlü gelişmesine katkı sağlayacaktır. Otizmli çocukların/bireylerin ihtiyaçlarının karşılandığı, doğa ile zengin öğrenme deneyimleri sunan, yaşam kalitesini artıran sağlıklı mekânların yaratılması sorumluluğunda olan mimarlık, çocukların hayatını olumlu yönde değiştirerek geleceğin şekillendirilmesinde etkili olacaktır. Bireyin çevreden bağımsız olmadığı dikkate alındığında, sadece bireye yönelik çözümlerin üretilmesi yetersiz kalacaktır. Bu kapsamda, bina ölçeğinden kent ölçeğine kadar geniş yelpazede geliştirilecek biyofilik tasarımlar, sadece otizmli çocukların yaşamında değil, aynı zamanda onlarla etkileşimde bulunan aileler, öğretmenler, terapistler ve toplum 
açısından da faydalı olacaktır. Disiplinlerarası anlayışla üretilen başarılı uygulamalar, doğaya karşı yeni bir bilincin oluşmasına da katkı sağlayacaktır.

\section{Etik Standart İle Uyumluluk}

Çıkar Çatışması: Yazar herhangi bir çıkar çatılması olmadığııı beyan eder.

Etik Kurul İzni: Etik Kurul iznine gerek yoktur.

Finansal Destek: Yoktur

TEŞEKKÜR: Atölye sürecinin yönetilmesinde katkılarını esirgemeyen Arş. Gör. Dr. Gökben Pala Azsöz'e, Arş. Gör. Dilara Sena Kılıç’a ve Mimar Tuğba Darendelioğlu'na, ayrıca Kırklareli Üniversitesi Mimarlık Bölümü Mimari Proje IV dersi öğrencilerine teşekkür ederim.

\section{KAYNAKÇA:}

Arslan, K. (2020). Otizmli Çocuğu Olan Ailelerin Dayanıklılığına Etki Eden Faktörlerin İncelenmesi. Doktora Tezi, Hacettepe Üniversitesi Sosyal Bilimler Enstitüsü Sosyal Hizmet Anabilim Dalı, Ankara.

Ayaz, A. (2019). Antalya Büyükşehir Özel Eğitim Okulu ve Rehabilitasyon Merkezi İçin İyileştirme Bahçesi Örneği. Yüksek Lisans Tezi, Süleyman Demirel Üniversitesi Fen Bilimleri Enstitüsü, Peyzaj Mimarlığı Anabilim Dalı, Isparta.

Beaver, C. (2006). "Designing Environments for Children and Adults with ASD," 2nd World Autism Conference, Cape Town, South Africa.

Barakat, H.A.E.R.A. and El-Sayad, B.Z. (2019). Nature as a Healer for Autistic Children, Alexandria Eng. J., 58 (1) (2019), pp. 353-366.

Bass, M. M., Duchowny, C. A., ve Llabre, M. M. (2009). The Effect of Therapeutic Horseback Riding on Social Functioning in Children with Autism. Journal of Autism and Developmental Disorders, 39, (ss.1261-1267).

Blom, M., (2013), Biophilic Architecture and its Influence on Human Behaviour and Well-being: A Proposed Urban Multi-Use Office Park Development, MSc Thesis, University of KwaZulu Natal Durban, South Africa.

Browning, W. D., Ryan, C. O., \& Clancy, J. O. (2014). 14 Patterns of Biophilic Design: Improving Health\&Well-Being in the Built Environment. In W. D. Browning (Ed.), (pp. 64). Retrieved from terrapinbrightgreen.com

Burak, Y. ve Ahmetoğlu, E. (2020). Otizm Spektrum Bozukluğu Olan Çocukların Kaynaştırılması ve Bütünleştirilmesinde Öğretmenlerle İlgili Değişkenlerin İncelenmesi. Elektronik Sosyal Bilimler Dergisi Cilt: 19, Sayı: 73. (ss. 478-503).

Çeşmeci, R., (2020). Afyonkarahisar Özel Eğitim ve Rehabilitasyon Merkezi, https://www.arkitera.com/proje/afyonkarahisar-ozel-egitim-ve-rehabilitasyon-merkezi/ (Erişim Tarihi: 24.04.2021).

Çırak, M., (2008). Mimaride Biçimin Görsel Etkisi: Tasarımcı Hedefi ve Kullanıcı üzerinden Bir Araştırma, Yüksek Lisans Tezi, Çukurova Üniversitesi Fen Bilimleri Enstitüsü, Konya.

Day, C., (2004). Places of the Soul: Architecture and Environmental Design as a Healing Art. Oxford: Elsevier.

Demirbaş, G. U. and Ö. O. Demirbaş. (2019). "The Interface between Landscape Architecture and Interior Architecture in the Context of Biophilic Design: Comparison of the Educational Programs." Turkish Journal of Landscape Research (2)2: 50-60.

Duman, Ü. (2017). Evrensel Tasarımın Kamusal Yapılarda Engelliler İçin Önemi: K.K.T.C. İçişleri Bakanlığı Binasının İncelenmesi, Yüksek Lisans Tezi, Yakın Doğu Üniversitesi Fen Bilimleri Enstitüsü, Lefkoşa, Kıbrıs. 
Elafifi, S. and Farid, M.M.A. (2020). Architectural Design: Towards Autism Spectrum Disorder Wellbeing. International Journal Of Engineering Research And Development, Volume 16, Issue 12. (pp. 48-60).

Ergül, H. (2015). Mimarlığın İhmal edilen Sosyal ve Toplumsal Yönü, ISITES2015, Valencia, Spain, (pp.1070-1079).

Fromm, E. (1964) The Heart of Man. New York, USA: Harper and Row.

Genç, G., Arslan, S. S. ve Beyhan, F. (2018). Biyofilik Kavramının Tarihi Binalar Bağlamında Değerlendirilmesi: Tokat Mustafa Ağa Hamamı. Uluslararası Sosyal Araştırmalar Dergisi, 11(58), (ss. 363-372).

Humphreys, S. (2008). Architecture and Autism, UDDA, Hasselt.

Issa, S.A. (2017). Architecture and Students with Autism: Exploring Strategies for Their Inclusion in Society Mainstream, World Academy of Science, Engineering and Technology, International Journal of Educational and Pedagogical Sciences, Vol:11, No:8, (pp. 2141-2146).

Joye, Y., 2007, A Tentative Argument for the Inclusion of Nature-Based Forms in Architecture, Universiteit Gent, Faculteit Letteren en Wijsbegeerte, The Degree of Doctor of Philosophy.

Kayıhan, K., Güney, S. ve Ünal F., (2018). Biophilia as the Main Design Question in Architectural Design Studio Teaching. Megaron, 13(1):1-12.

Kellert, S. R. C., Elizabeth F. (2015). The Practice of Biophilic Design. Retrieved from www.biophilicdesign.com website

Kellert, S. R. and Heerwagen J. H., Mador M. L., (2008). Biophilic Design - The Theory. Science and Practice of Bringing Buildings to Life., Hoboken, NJ: John Wiley and Sons. Inc.

Kumar, D. S., Purani, K. ve Viswanathan, S. A. (2020). Biomorphic Design Forms in Servicescapes. Journal of Services Marketing Volume 34. Number 6. (ss. 847-867).

Martin, F., ve Farnum, J. (2002). Animal-assisted Therapy for Children with Pervasive Developmental Disorders. Western Journal of Nursing Research, 24 (6), (ss.657-670).

Minsolmaz Yeler, G. (2012). Mimarlıkta Biyomorfizm, Doktora Tezi, Mimarlık Bölümü, Fen Bilimleri Entitüsü, Trakya Üniversitesi, Edirne, Türkiye.

Mostafa, M., (2008). "Architecture for Autism. Concepts of Design Intervention for the Autistic User." IJAR International Journal of Architectural Research 2, No. 1, (pp. 189-211).

Mostafa,M. (2014). Architecture for Autism: Autism ASPECTSSTM in School Design, Archnet-IJAR, Volume 8, Issue 1, (pp. 143-158).

Muslu, K. G. ve Conk, Z. (2011). Hayvan Destekli Uygulamalar ve Çocuklarda Kullanımı. Dokuz Eylül Üniversitesi Hemşirelik Yüksekokulu Elektronik Dergisi, (ss. 83-88).

Nealy, C.E., O’hare, L., Powers, J.D. ve Swick, D.C. (2012). The impact of Autism Spectrum Disorders on the Family: A Qualitative Study of Mothers' Perspectives. Journal of Family Social Work, 15, (ss.187-201).

Özkubat, U., Özdemir, S., Selimoğlu, Ö. G. ve Törev, G. (2014). Otizme Yolculuk: Otizmli Çocuğa Sahip Ebeveynlerin Sosyal Destek Algılarına İlişkin Görüşleri. Ondokuz Mayıs Üniversitesi Eğitim Fakültesi Dergisi 2014, 33(1). (ss. 323348).

Pomana, A. (2015). Architecture for Autism. Improving Designs for Autistic Integration Conference: ICAR March 2015, Bucharest, (pp. 1-15).

Ryan, C. O., Browning, W. D., Clancy, J. O., Andrews, S. L., \& Kallianpurkar, N. B. (2014). Biophilic Design Patterns: Emerging Nature-Based Parameters for Health and Well-Being in the Built Environment. ArchNet-IJAR: International Journal of Architectural Research, 8(2), 62. 
Sams, M. J., Fortney, E. V., ve Willenbring, S. (2006). Occupational Therapy Incorporating Animals for Children with Autism: A Pilot Investigation. American Occupational Therapy Association, 60 (3), (ss.268-274).

School Construction News (2021). How Biophilic Design Helps Bancroft's Autistic Students, https://schoolconstructionnews.com/2018/05/04/biophilic-bancroft-autism/ 2021 School Construction News (Erişim Tarihi: 24.05.2021).

Scott, I, (2009). "Designing Learning Spaces for Children on the Autism Spectrum." Good Autism Practice (GAP) Volume 10, no. 1 (May, 2009): 36-51.

Shahmahommadian, H. ve Shahmahommadian, H. (2020). Designing an Autism Healing Center with Emphasis on Nature Therapy. The International Journal of Whole Person Care, 7(1), (pp. 53-54).

Şensoy, N. (2017). Otizm Spektrum Bozukluğu Olan Bireyler için Duyu Bahçesi Tasarımı. Inonu University Journal of Arts and Design, 7(15). (ss.115-128).

Tandoğan, O. (2017). Evrensel Tasarım Kavramı: Kentsel Peyzaj İle İlgili Örnekler. Artium, 5 (2) , 51-66.

Tırpan, A. F., (2020). “Uyum” Otizmli Çocuklar İçin Eğitim Merkezi, https://www.arkitera.com/proje/uyum-otizmlicocuklar-icin-egitim-merkezi/ (Erişim Tarihi: 24.04.2021).

Tohum Otizm Vakfi, 2020, https:/www.tohumotizm.org.tr/otizm/otizm-spektrum-bozuklugu/, (Erişim Tarihi: 24.06.2021).

Tola, G., Talu, V., Congiu, T., Bain, P. and Lindert, J. (2021). Built Environment Design and People with Autism Spectrum Disorder (ASD): A Scoping Review. International Journal of Environmental Research and Public Health, 18(6), 3203, (pp.1-15).

Vázquez, S. F. and Torres, S. A., 2013, Autism and Architecture, Volume II, Recent Advances in Autism Spectrum Disorders -Edited by Michael Fitzgerald, IntechOpen.

Wilson, E.O. (1984) Biophilia. Massachusetts: Harvard University Press.

Yurtgün, H. Ö. (2020). Biyofilik Tasarım Kriterlerinin Açık Ofisler Üzerinden Değerlendirilmesi. IDA: International Design and Art Journal, 2(2), s.281-296.

Zeyrek, Çepehan, İ. ve Güller, E. (2020). Evrensel Tasarım Kapsamında Herkes İçin Erişilebilir Tasarım, Sosyal Politika Çalışmaları Dergisi, Erişilebilirlik Özel Sayısı, CİLT-2 ss. 383-410. 